Article

\title{
The "Eco-Effectiveness" of Agritourism Dynamics in Italy and Spain: A Tool for Evaluating Regional Sustainability
}

\author{
Angelo Belliggiano ${ }^{1} * \mathbb{C}$, Eugenio Cejudo Garcia ${ }^{2} \mathbb{D}$, Marilena Labianca ${ }^{3}$, \\ Francisco Navarro Valverde ${ }^{2}\left(\mathbb{D}\right.$ and Stefano De Rubertis ${ }^{3}$ \\ 1 Department of Agricultural, Environmental and Food Sciences, University of Molise, \\ 86100 Campobasso, Italy \\ 2 Department of Human Geography, University of Granada, 18071 Granada, Spain; cejudo@ugr.es (E.C.G.); \\ favalver@ugr.es (F.N.V.) \\ 3 Department of Scienze dell'Economia, University of Salento, 73100 Lecce, Italy; \\ labiancamarilena@libero.it (M.L.); stefano.derubertis@unisalento.it (S.D.R.) \\ * Correspondence: belliggi@unimol.it
}

Received: 23 July 2020; Accepted: 27 August 2020; Published: 30 August 2020

check for updates

\begin{abstract}
Rural tourism has commonly been identified as one of the main areas of application of the principles of sustainable tourism, but the literature has typically focused solely on the ecological dimension, particularly when referring to agritourism. This study presents a new approach to assessing the "eco-effectiveness" of the evolutionary dynamics of agritourism, as applied in a study of NUTS-2 regions in two European countries (Spain and Italy) that have implemented similar rural development strategies. To this end, a synthetic sustainability index was developed using the Index Decomposition Analysis (IDA) technique. The last period of the European Agricultural Fund for Rural Development (EAFRD) 2007-2013 was chosen for the study in order to analyze the outcomes of a programming cycle focusing on the diversification of agriculture through tourism. The results show that the sustainability of agritourism growth is not homogeneous and has specific features in different regions of the same country. In some cases, there were more similarities with regions from other countries. This tool could help evaluate the impact of agritourism and facilitate comparisons between different regions, in this way supporting the process of transition from a linear to a circular economy.
\end{abstract}

Keywords: agritourism; eco-effectiveness; rural development; circular economy; Index Decomposition Analysis (IDA)

\section{Introduction}

Many studies have stressed the need for a decisive transition from a linear to a circular economy and to this end have proposed good practices and strategies at different scales. Most of these studies have focused on physical and environmental sustainability, which, although important, should not be the sole dimension of such models.

Studies of the agricultural sector and rural development typically take the same approach. Academic interest in agritourism, also known as 'farm tourism' or 'farm holidays,' has increased due to its inherent value as a part of sustainable development strategies and because of the opportunities it offers in terms of the diversification of economic activity in rural areas and additional income streams that can supplement revenues from farming [1-5].

The term "agritourism" has various definitions, not all of which are explicitly linked to agricultural activities. Philip et al. [6] identified different types of agritourism and categorized them on the basis of the level and/or methods of participation of the tourists (i.e., non-working farm; working farm-passive 
contact; working farm-indirect contact; working farm direct contact-staged; working farm direct contact-authentic). These different forms of agritourism have different implications in terms of the extent and level of their contribution to rural development.

In this study we decided to focus our analysis on the "working farm" category, given the fundamental role of agriculture in the territorial regeneration of rural areas which are facing a seemingly inexorable process of abandonment due to evident "market failures."

Agritourism is at the interface between two economic sectors (agriculture and tourism) and involves a wide variety of sustainability-related practices and conditions, ranging from extremely poor to excellent. This type of tourism can be a catalyst for numerous rural development processes. At the micro level, the sector opens up new markets [7-9] linked to rural and experiential tourism [10,11] that enable farmers to escape from economic hardship [12]. It also increases employment opportunities, particularly for women and young people [13]. At a regional level, agritourism is becoming increasingly important as an instrument of agricultural diversification, a tendency encouraged by European policies [14]. These policies were initially aimed at freeing up agricultural markets and increasing profitability, but have progressively acquired a central role in the wider discourse about the resilience of rural areas [15].

The diversification of the rural economy through tourism has become an important, recurrent theme of integrated territorial development strategies, especially in the LEADER program, one of the EU's most important rural development strategies [16-18]. Over its almost 30-year history, LEADER has evolved into a theoretical approach, a method for bringing about rural development, which has built on recent theories of neo-endogenous rural development. After its successful implementation in rural areas of the European Union, it is now being transferred to other rural areas around the world. The main features of the LEADER Program are networking, a territorial perspective, integrated and multisectoral actions, local decision-making, economic diversification, a bottom-up approach, innovation, and public-private partnerships in the form of Local Action Groups or LAGs. The LAGs have contributed to the widespread development of agritourism in Europe, which has helped regenerate many rural areas, as it offers significant opportunities for economic diversification in many local communities which are currently suffering severe demographic crises $[19,20]$. However, insufficient attention has been given to sustainability issues. Agritourism (and rural tourism in general) has commonly been identified as one of the main areas in which the principles of sustainable tourism have been applied [21], but the literature on this question has typically focused solely on the ecological dimension [22,23], and has tended to ignore the important social, economic, and institutional dimensions of sustainability. Neglect of these dimensions can make the process of conversion from a "linear" to a "circular" economy slower and more problematic at all levels, from individual companies to the entire sector.

Previous researchers analyzed a range of tourism sustainability indicators [24-42]. Most studies attempt to assess the sustainability of tourism growth in general, and a few apply these indicators to specific cases [42-44], focusing in particular on rural tourism [41,45-47], or dealing exclusively with economic and environmental sustainability [45].

These indicators (including those proposed by the EC [48], and the WTO [49]) are always aimed at assessing the overall impact on destinations "and there is no consensus among scholars regarding a universal list of indicators capable of revealing the sustainability level of various destinations" ([42], p. 69).

Agritourism has been identified as an important factor in rural development processes and in the implementation of LEADER programs. In view of this, in this study we propose a tool for evaluating the "eco-effectiveness" [50] of the evolutionary dynamics of agritourism in various European regions. The aim of this tool is to facilitate the repositioning of development objectives from eco-efficient to eco-effective, thus introducing a new critical perspective in terms of consolidated approaches over time, through which farm holidays can be interpreted as an unconditionally useful and desirable part of the rural development process [51].

In the next section, the sustainability aspects considered in the creation of this tool are presented, and the theoretical context is discussed. Section 3 describes the construction of a synthetic sustainability index in relation to the concept of eco-effectiveness, in which Index Decomposition Analysis (IDA) [52], 
is applied to identify specific agritourism flows according to factors that act as proxies for the ecological, economic, social, and institutional dimensions of sustainability. The sustainability index is then applied to rural regions of Italy and Spain (NUTS2), and the similarities and differences are highlighted before making an overall assessment (Sections 4 and 5).

\section{Multi-Dimensional Sustainability (The Theoretical Background)}

Due to obligations acquired under various WTO agreements, EU intervention in agricultural markets has been progressively declining and some of the resources have been shifted to address the issues of rural development. The urgency of such action and its central role in maintaining the ecological balance had already been stressed by the Communication from the Commission to the Council entitled "the Future of Rural Society" [53], which emphasized the importance of multifunctionality.

Although multifunctionality is often misunderstood and incorrectly associated with "diversification" and "multi-activity" [54], it does in fact have a considerable affinity with rural tourism [55], and could offer a means of internalizing the non-commodity outputs of agriculture and more generally of rural economies, thus reducing the market failures that affect the most marginal and fragile areas in particular.

Increased social and economic benefits can be obtained from rural activities that are not specifically agricultural. These include experiential tourism in rural areas for which there is growing demand [56], and which also involves a commitment to the conservation of natural resources. This combination of approaches can lead to new forms of differentiation in the products or activities on offer to tourists, which could include other uses of the material and immaterial heritage of rural areas, and in particular those directly related to agricultural activities, i.e., "Agricultural Heritage" [57,58]. These ideas are also associated with the drive towards more equitable and ecologically sustainable development of the planet. In addition, a focus on the everyday and on local identity can revitalize and diversify the economy, by taking advantage of endogenous resources via a more post-productivist outlook [59]. Initiatives of this kind enable declining rural areas to adapt better and become more resilient to the complex and uncertain scenarios produced by economic globalization. The relationship between tourism and agriculture, manifested for example in agritourism [60,61], wine tourism [62,63], or olive oil tourism [64], has led to the revaluation of heritage in areas of agricultural monoculture and in areas with significant traditional agricultural and livestock practices and customs. Landscapes have also been re-evaluated by identifying the elements and support necessary for a more diverse, more sustainable productive system [65]. This could be linked to water [66,67], to agroforestry systems such as pastureland [68], or to the socio-territorial structure itself, as a model of settlement and cultural heritage. This may be associated with a localized system of governance dispersed throughout the territory, which can support the preservation of land and locally control its uses [69].

The demand for slow, experiential rural tourism also encourages the development of agriculture-related activities. The farms involved begin to earn significant additional income that can help them cover their production costs, particularly in the case of family-run farms. At a wider level, this enables people, and especially young people, to continue in farming, so reducing the depopulation of many rural areas.

However, rural destinations situated near major tourist attractions, such as cities, seaside or mountain resorts, may be affected by the organizational models typical of mass tourism. These can lead to uncontrolled increases in and/or overcapacity of the facilities or services created to cater for these forms of tourism, which are mainly seasonal, thus limiting or reducing the competitiveness and potential profitability of smaller facilities that combine tourist services with agriculture or craft-based activities. Another side effect is the questionable standardization of the experiential activities on offer, which often consist simply of representations of the basic farming rituals, rather than offering opportunities to share the lifestyles of families or host communities [70,71].

Agritourism offers farmers and underemployed residents of rural areas the opportunity to supplement their incomes while remaining in their home community [72], and can contribute to the 
maintenance of natural heritage. This may be a solution to the long-standing risk of low productivity in local businesses or workforces, as it can facilitate the necessary generational turnover by offering young people the opportunities to fulfil their professional ambitions in sectors other than the strictly agricultural, while remaining in their home areas. Agritourism can therefore have positive demographic effects, particularly in the areas most affected by depopulation.

Regional policymakers have therefore tended to focus their attention on eco-efficiency in order to reduce the negative effects of agritourism development (such as energy improvement of facilities). By "doing things right" instead of "doing the right things," they should be able to promote "a synergistic relationship between ecological and economic systems able to restore and enhance the natural environment while allowing businesses to succeed" ([73], p. 11), so avoiding oversimplifying a concept that is in fact quite complex and multidimensional [74]. In addition to characterizing the Integrated Rural Tourism Model (IRT) [55], this approach also constitutes the most recent orientation of the circular economy.

Thus, rural tourism faces various problems that can reduce its economic, social, and environmental sustainability, and may lead to institutional challenges such as the mismatch between public and private agents, the preponderance of offerings based on stereotypes of what is popularly considered as "rural," the widespread presence of microentrepreneurs [75], the addition of a second income stream for families, and a reduction in environmental and institutional sustainability, due to the low local participation and representation in local governments and institutions.

The sustainability of economic development processes in general, and rural tourism in particular, should therefore be understood not only as a chance to perpetuate the ecological systems on which they act over time, but also as an opportunity to avoid the erosion of the social, economic, and institutional capital on which they are based. It is therefore crucial for the sector to adapt and move towards circular economic approaches, which allow synergistic relationships between ecological and economic systems [73]. These synergies, in addition to ensuring the maintenance of environmental heritage [76-79], can also allow enable the local economy to grow [50].

These combinations appear to be well represented by the concept of Integrated Rural Tourism (IRT), a tourism model based on a closely integrated combination of all the resources (natural, cultural, economic, human, and social) and all the actors in a particular territory. In this way every single component involved in the process is considered, despite their varying degrees of participation [55]. The term 'integrated approach' therefore emphasizes the possibility of effectively combining the local tourism offering within a single network formed by the cooperation and collaboration of all the different agents involved.

The benefits can be both direct and indirect. Direct benefits include an increase in the territorial added value by improving the profitability of the available production factors (economic benefits), in which buildings and land play a significant role. They can be viewed as a rural reinterpretation of the drive to reverse obsolescence that Hollander et al. [80], consider one of the key approaches in the circular economy. Indirect benefits include those related to the retraining of the family workforce of agricultural enterprises in tourism-related skills, which can help ensure the survival of businesses and wider communities (conservation benefits).

Through IRT, the intrinsic value of the multifunctionality of agriculture can be recovered (such as the conservation of the agricultural landscape). Other functions are, albeit often erroneously, linked to it, such as the diversification of production activities and/or multi-activities of the family workforce (developmental benefits), as families can devote a proportion of their time and professional lives to looking after and involving tourists in day-to-day rural activities, thus producing mutually beneficial effects for both tourists and host communities (experiential benefits). Other benefits of IRT could arise from facilitating coordination in the design of public rural development activities, broadening the composition of mixed partnerships made up of public institutions, economic operators, and other local stakeholders (synergistic benefits), and regenerating local economies through the introduction of innovations aimed at "slowing or closing material flows" [81]. 
This last aspect reveals the importance of the institutional dimension of the sustainability of rural tourism [79], namely the capacity of public institutions to reconcile conflicts between different local interests, a question that has often been neglected or underestimated in the implementation of projects financed through public resources in many rural programs. This highlights the fact that even the best thought-out projects can fail without appropriate financing, which can then have a significant knock-on effect on the other dimensions of sustainability.

Institutional sustainability is considered useful and important in other fields, but has not been fully considered in agriculture probably due to the basic ecological meaning attributed to agricultural sustainability. The result is that organizational changes related to development and institutional sustainability have been implemented thanks to the application within rural development programs of the LEADER approach, in which public-private partnerships have been established in the form of Local Action Groups (LAGs). These groups have helped reduce institutional disputes both between the different actors and between their sometimes conflicting business interest. This has been achieved, firstly, by promoting genuine participation of all stakeholders in the different phases of planning, management and execution of rural development strategies and secondly, because the LAGs are institutionalized collectives that are generally representative of the interests of the tourism sector and of public institutions [82]. In addition, farming-related projects focus on enhancing the value of local agricultural products with a strong territorial identity, emphasizing social identification and coherence between the different development actions, including support for SMEs and rural tourism ([83], p. 56). Ever since they were first implemented in 1991, one of the main aims of the LEADER initiatives has been to promote rural tourism, and priority has been given to economic criteria and increasing the supply of rural tourism facilities, with less attention being paid to planning and the demand for these facilities.

In Italy, for example, 55,000 LEADER projects were planned (for 3.5 billion Euros) between 1991 and the current programming period, half of which concerned the tourist development of rural areas and the accommodation and recreational capacity of farms [84].

In Spain, during the period 1994-2007, LEADER II and LEADER + (together with similar rural development programs called PRODER and AGADER) accounted for $24.3 \%$ of total investment in rural tourism in Spain, creating 39,587 new tourist accommodation facilities. Rural tourism was even more important during the initial period, known as LEADER I (1991-1993), when rural tourism projects made up $43.1 \%$ of all implemented projects. Investment in these projects came to more than half the total investment in LEADER projects, and 30,950 new tourist accommodation facilities were set up ([83], p. 265).

The following program period (2007-2013) saw a significant reduction in public spending on tourism projects, due both to the economic crisis of 2007 and in some cases to the excessive proliferation of accommodation on offer. In this period, projects tended to focus more on marketing campaigns and other complementary activities, aimed mainly at increasing tourism flows.

Therefore, rural development programs that are openly sustainability-oriented or assessed as sustainably compliant could paradoxically encounter limitations in terms of their ability to maintain their institutional structure when the funding period comes to an end, due to the incapacity of individual promoters to survive without public funding [85]. In addition, these types of public initiatives have rarely been carried out, or have been done so erratically or unequally [86].

Another important aspect of the institutional sustainability of tourism linked to rural development practices is the evaluation of the effectiveness and efficiency of EU resource allocation, as rural development programs have been the main driver of tourism in many areas. However, although the EU regards such evaluation as mandatory, the impact of tourism in rural territories has not been fully considered in the methods used [87]. The problems inherent in a multilevel governance system and the principle of subsidiarity for rural development have been evident and questions were raised during the planning phase established by the EU in the period 2007-2013. In addition, although a participatory approach has been taken in tourism planning processes, this has only been addressed 
from a supply-side perspective. Rural tourism strategies based on the needs and characteristics of the demand for this product have rarely been considered, and this has resulted in an excess supply of accommodation and low levels of quality in certain destinations or regions [88].

Institutional sustainability should therefore be the main priority of IRT and should result from a combination of the endogenous resources of a territory, as this implicitly engages rural communities in the development strategy regardless of the program or the chosen public funding source. All local actors will then have the opportunity to integrate and participate, thus increasing the chance of success of their respective individual activities [89]. As part of the move towards diversification through tourism aimed at the territorial regeneration of critical rural areas, agri-food production must also be considered, due to its intrinsic role in the rural experience being offered to the tourist, and as a symbolic and evocative expression of local identities [90].

\section{Methodology}

Despite being part of the same policies of diversification of the range of agricultural products, particularly in the LEADER areas and more recently as the second pillar of the CAP, agritourism has developed significantly in many rural areas of Europe and may have had a specific influence on the various dimensions of sustainability described above. This may in turn have led to significant differences between regions in the same country, or perhaps to similarities between regions in different countries. To this end we performed an international comparative study between the NUTS-2 regions of Italy and Spain, which could also test the comparative effectiveness of the model. Spain and Italy were chosen because of the important similarities between the two countries: their geographic situation in the Mediterranean Basin, various common practices in the implementation of Rural Development Programmes (RDPs) [91], and the importance of tourism in their respective economies. Agritourism is a rapidly expanding phenomenon in both countries, although its overall value in Italy $(11 \%$ of the value of primary agricultural production) is much higher than in Spain (1.1\%) [92].

In this study we propose a specific tool (SSI) for assessing farm tourism, which is designed to support the policies of the sector at both regional and European levels. It is an easy-to-use tool that requires few data sets, most of which are readily available:

- number of tourist arrivals and nights spent in the accommodation;

- capacity of tourist accommodation establishments.

Thus, four elementary variables were used in this study: the number of rural tourism facilities $(\mathrm{N})$; their size in terms of beds (B); the number of tourist arrivals (A); and the nights spent (D). These are recorded at both NUTS-2 and NUTS-3 levels, by the ISTAT (Italian National Institute of Statistics) in Italy and by the INE (National Statistics Institute) in Spain.

These variables can thus be combined in various indices, particularly if treated diachronically, so as to identify the impact of agritourism on the regions and its implications for sustainability, in particular through rural development policies.

We decomposed the total nights spent in a region using the following equation:

$$
Q=\sum_{i} N \cdot \frac{N_{i}}{N} \cdot \frac{B_{i}}{N_{i}} \cdot \frac{A_{i}}{B_{i}} \cdot \frac{Q_{i}}{A_{i}}
$$

where:

$N=$ structures in the region

$N_{i}=$ structures in $i$-th province of the region

$B_{i}=$ beds in $i$-th province of the region

$A_{i}=$ arrivals in $i$-th province of the region

$Q_{i}=$ nights spent in $i$-th province of the region 
In this paper we assume that the average stay (nights spent/arrivals, $Q_{i} / A_{i}=L$ ), and the size of the accommodation facilities (beds/facilities, $B_{i} / N_{i}=C$ ) compared with the intensity of the incoming flows (arrivals/beds, $A_{i} / B_{i}=I$ ) can be regarded as good indicators of the socioeconomic sustainability of agritourism. Indeed, with the same total number of nights spent, an average longer stay could indicate that the original idea of agritourism (an experiential holiday on a working farm) is becoming distorted: a wider range of services should be offered, in order to meet more complex, more varied needs and expectations, although increasing interest in agritourism could encourage farmers to divert time and resources from their main activity (agriculture), whose "authenticity" is the prime reason for the holiday. In addition, with the same total number of nights, a shorter average stay guarantees a higher number of arrivals and therefore an increased number of external contacts. Similarly, a shorter average stay helps maximize the effects of campaigns promoting local products and the local area, as more potential customers can be reached with the same level of resources. Similar arguments could be applied to the accommodation capacity and the number of visitors coming to each farm: very high numbers of tourists visiting a small number of businesses each with a large number of beds, would reduce the central function of agriculture within the business structure.

Other assumptions are as follows:

- the variations in the number of facilities $(N)$, their size $(C)$, and the number of nights spent in these facilities during the period being studied $(D)$ can be used to estimate ecological sustainability;

- the level of use of the facilities or Occupancy Rate $(O R=Q T / P S$, where $Q T$ is the total number of nights spent at time $T$ and $P S$ is obtained by multiplying the number of beds by 365 days) is a useful indicator of whether the supply of accommodation is suitably in line with demand;

- the territorial concentration of agritourism, as expressed by the ratio of the facilities in the i-th province with respect to the regional total $(\mathrm{Ni} / \mathrm{N}=\mathrm{S})$. This indicates the density of agritourism facilities in particular areas, which in turn is a good indicator of institutional sustainability. It also offers an indirect estimate of cultural sustainability.

With this in mind, a sufficiently large observation interval (2005-2017) was chosen to capture the ex-ante and ex-post situations prevailing before and after the last completed program period (2007-2013). During this period, the economic potential of tourism as a diversification from agriculture was recognized to a greater extent than before, for both the farms themselves and for the territory as a whole.

The value of these indicators is obviously dependent on the methods of application and on the extent to which specific regions of each country implemented the program in their respective RDPs. The timing of implementation of these policies is another important issue, although 2017 should generally be considered as the last year of the survey covering that particular programming period.

Thus, in order to establish the relative weights of these components in terms of the sharp increase in the sustainability of agritourism observed in recent years in both countries, we decomposed the changes in the number of nights spent $(Q)$, as recorded at the beginning and the end of the observation period $\left(D=Q^{T} / Q^{0}\right)$. To this end, we examined the three-year periods from 2005-2007 and 2015-2017, so as to reduce the effect of any contingent anomalies, through an adaptation of the IDA (Index Decomposition Analysis). This technique is commonly used for the analysis of the dynamics of energy consumption [93] but has also been applied recently to interpret tourist flows [52] and their sustainability in less developed regions [94].

This technique enables us to break down the changes in 'nights spent' into various factors attributable to the previously identified sustainability indices, according to the following equation:

$$
D=Q^{T} / Q^{0}=D_{N} \cdot D_{S} \cdot D_{C} \cdot D_{I} \cdot D_{L}
$$

where:

$D=$ variation in the total nights spent in agritourism facilities during the study period $(0-T)$

$Q^{T}=$ total nights spent at time $T$ 
$Q^{0}=$ total nights spent at time 0

$D_{N}=$ variation in $D$ attributable to the number of agritourism facilities $(N)$

$D_{S}=$ variation in $D$ attributable to the provincial concentration of agritourism facilities (S)

$D_{C}=$ variation in $D$ attributable to the size of agritourism facilities $(C)$

$D_{I}=$ variation in $D$ attributable to the arrivals/beds ratio $(I)$

$D_{L}=$ variation in $D$ attributable to the nights spent/arrivals ratio $(L)$

This enables us to calculate the values of the factors and therefore the proportion of the variation in nights spent that can be attributed to a particular dimension of sustainability. This is done by applying the Logarithmic Mean Divisia Index method I (LMDI I) [95], using the following five equations:

$$
\begin{aligned}
D_{N} & =\exp \left(\sum_{i}\left(\bar{Q}_{i} / \bar{Q}\right) \ln \left(N_{i}^{T} / N_{i}^{0}\right)\right) ; \\
D_{S} & =\exp \left(\sum_{i}\left(\bar{Q}_{i} / \bar{Q}\right) \ln \left(S_{i}^{T} / S_{i}^{0}\right)\right) ; \\
D_{C} & =\exp \left(\sum_{i}\left(\bar{Q}_{i} / \bar{Q}\right) \ln \left(C_{i}^{T} / C_{i}^{0}\right)\right) ; \\
D_{I} & =\exp \left(\sum_{i}\left(\bar{Q}_{i} / \bar{Q}\right) \ln \left(I_{i}^{T} / I_{i}^{0}\right)\right) ; \\
D_{L} & =\exp \left(\sum_{i}\left(\bar{Q}_{i} / \bar{Q}\right) \ln \left(L_{i}^{T} / L_{i}^{0}\right)\right)
\end{aligned}
$$

where:

$$
\bar{Q}_{i}=\frac{Q_{i}^{T}-Q_{i}^{0}}{\ln Q_{i}^{T}-\ln Q_{i}^{0}}
$$

An initial estimate of the sustainability of the growth in farm tourism can be obtained by aggregating the value of the factors returned by IDA into two distinct components. The first, defined as "rural-tourism diffusion" (RD), represents the observed increase in rural tourism, and is therefore expressed by the product of the structural indices $(N$ and $C)$, the spatial concentration $(S)$, and the duration of the stay $(L)$

$$
\mathrm{RD}=D_{N} \cdot D_{S} \cdot D_{C} \cdot D_{L}
$$

The second component is represented exclusively by the "intensity factor" or rural-tourism rotation rate (RR), the index that expresses the bed turnover rate, which will be high if the agritourism facilities in the region have a high turnover. With the same nights spent, the growth in arrivals shows the increased ability of the region to attract tourists for short stays. As argued earlier, in this paper we assume that the short duration of the average stay is typical of the more authentically rural farms, therefore:

$$
\mathrm{RR}=D_{I}
$$

The value of RR can therefore also be considered as a proxy for the rural tourist offering in each region, which should be proportional to the number of arrivals $(A)$ and inversely proportional to both the number of beds and the length of the stay ( $L=$ nights spent/arrivals).

The possible combinations of RR and RD are therefore as follows:

(1) $\mathrm{RR}>1 ; \mathrm{RD} \leq 1$

(2) $\mathrm{RR}<1 ; \mathrm{RD}>1$

(3) $\mathrm{RR}>1$; RD $>1$, with $\mathrm{RR}>\mathrm{RD}$

(4) $\mathrm{RR}>1$; RD $>1$, with $\mathrm{RR}<\mathrm{RD}$

Combinations (1) and (3) represent ideal solutions in terms of economic, ecological, and social sustainability as in both cases a more efficient use of the facilities could compensate for both structural downsizing or any growth in the supply of accommodation that could be encouraged by a proportionate 
increase in arrivals. In such situations, agricultural incomes would be supplemented both by revenues from tourism and by increased income from the sales of farm produce.

Combinations (2) and (4) represent negative scenarios, produced respectively by situations of dissatisfaction and/or a fall in tourist demand, and by unjustified increases in the supply of agritourism accommodation or its non-ideal use (as manifested in longer stays). Scenarios of this kind have inevitable implications for corporate investments and could result in investors deciding to withdraw from the area, due to unsatisfactory rates of return.

A more immediate representation of the four combinations can be obtained from what we define as a synthetic indicator of eco-effectiveness and sustainability (synthetic sustainability index-SSI), expressed by the ratio of the other two indicators:

$$
\mathrm{SSI}=\mathrm{RR} / \mathrm{RD}
$$

In addition to expressing the degree of sustainability (for SSI values $>1$ ) of the growth processes recorded in different regions or countries, this tool enables us to make simultaneous internal and external comparisons.

In the following sections, in which we present and discuss the results, the SSI values in each region will be compared with the values of the corresponding components (rural-tourism diffusion factor- $\mathrm{RD}$ and intensity factor- $\mathrm{RR}$ ) and the gross marginal occupancy of the facilities (Occupancy Rate-OR).

The comparison between SSI and OR allows us to assess whether the supply of accommodation facilities is suitably in line with demand and to evaluate potential growth in sustainability.

\section{Results}

A comparison between Italy and Spain (Figure 1) shows that the growth in demand $(D>1)$ observed in both countries had a lower physical impact on agritourism facilities in Italy in terms of their average size $\left(D_{C}\right)$, although there was significant growth in arrivals (140.2\% compared to $106 \%$ in Spain) and a lower proportional increase in nights spent (93.7\% compared to $76 \%$ in Spain). These changes led to a fall in the average length of stay in both countries. Although accommodation capacity has increased at different rates in different places in the two countries, the general rate of increase has slowed down over time. The growth of flows in Spain was sustained by means of a net decrease in the OR (from 20.5 to $19.4 \%$ ), as highlighted by the better Italian performance in terms of the $D_{I}$ index.

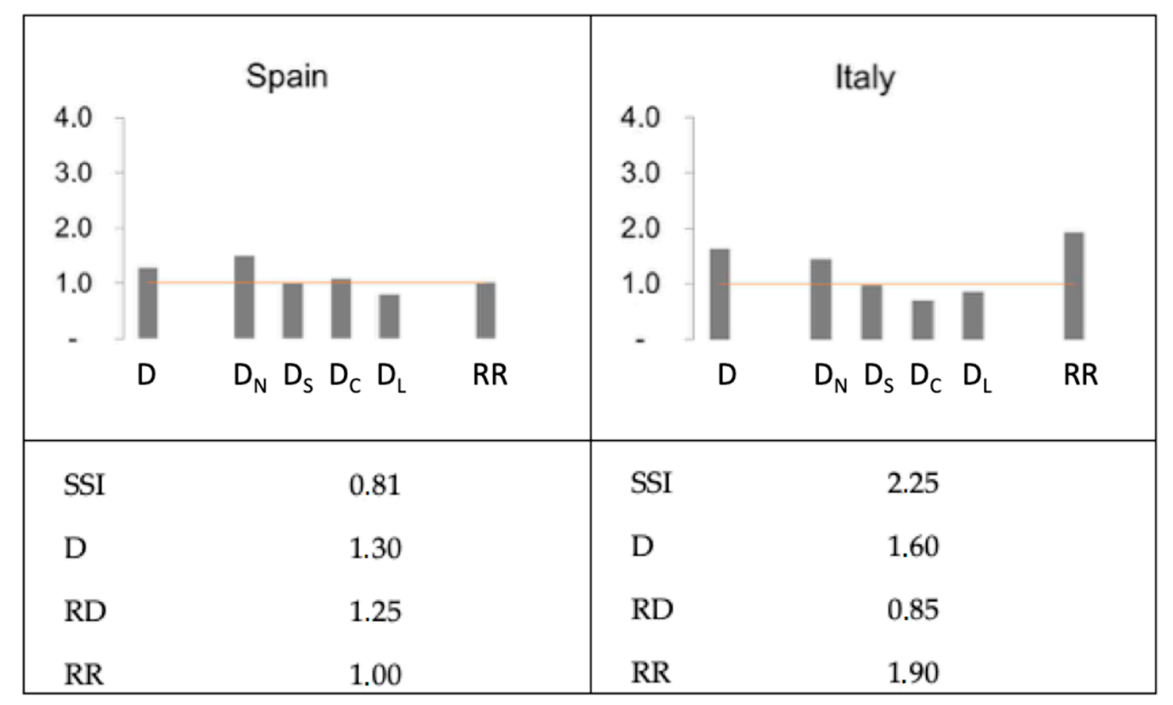

Figure 1. Synthetic sustainability index (SSI) values for Spain and Italy. The red line highlights the "threshold" value of 1 . Source: Drawn up by the authors using data provided by the Italian National Institute of Statistics (ISTAT) and National Statistics Institute (INE). 
The overall result indicates a higher sustainability index for agritourism in Italy (2.25) than in Spain (0.81).

Table 1 shows the changes in nights spent for each region in the two countries. The regions (NUTS-2) are ordered according to their SSI value.

Table 1. Changes in the number of nights spent in each region.

\begin{tabular}{|c|c|c|c|c|c|c|c|c|}
\hline Regions & SSI & $D$ & $D_{N}$ & $D_{S}$ & $D_{C}$ & $D_{L}$ & $D_{I}(\mathrm{RR})$ & RD \\
\hline Canarias & 3.23 & 1.10 & 0.83 & 1.02 & 1.16 & 0.60 & 1.89 & 0.58 \\
\hline Basilicata & 3.11 & 1.50 & 0.73 & 1.00 & 1.11 & 0.86 & 2.16 & 0.69 \\
\hline Valled' Aosta & 1.65 & 1.51 & 1.04 & 1.00 & 1.21 & 0.76 & 1.58 & 0.96 \\
\hline Murcia & 1.56 & 0.79 & 0.61 & 1.00 & 1.47 & 0.80 & 1.11 & 0.71 \\
\hline Lombardia & 1.39 & 2.92 & 1.60 & 1.00 & 1.05 & 0.86 & 2.02 & 1.45 \\
\hline Piemonte & 1.37 & 2.35 & 1.59 & 1.00 & 1.02 & 0.81 & 1.79 & 1.31 \\
\hline Abruzzo & 1.37 & 0.78 & 1.12 & 1.02 & 1.00 & 0.66 & 1.03 & 0.76 \\
\hline Cantabria & 1.34 & 1.11 & 1.13 & 1.00 & 0.98 & 0.82 & 1.22 & 0.91 \\
\hline Sicilia & 1.33 & 1.46 & 0.92 & 0.96 & 1.24 & 0.96 & 1.39 & 1.05 \\
\hline Trentino & 1.28 & 1.76 & 1.25 & 1.00 & 1.06 & 0.88 & 1.50 & 1.17 \\
\hline Galicia & 1.24 & 1.14 & 1.04 & 1.01 & 1.06 & 0.86 & 1.19 & 0.96 \\
\hline Navarra (C.F. de) & 1.07 & 1.15 & 1.41 & 1.00 & 1.08 & 0.68 & 1.11 & 1.04 \\
\hline Lazio & 1.05 & 0.78 & 0.80 & 1.50 & 1.63 & 0.44 & 0.91 & 0.86 \\
\hline Balears (Illes) & 0.97 & 2.01 & 1.74 & 1.00 & 1.13 & 0.73 & 1.40 & 1.44 \\
\hline Friuli & 0.92 & 2.35 & 1.67 & 1.00 & 1.05 & 0.91 & 1.47 & 1.60 \\
\hline Umbria & 0.91 & 1.14 & 1.26 & 1.00 & 1.00 & 0.88 & 1.02 & 1.12 \\
\hline Marche & 0.91 & 2.01 & 1.57 & 1.00 & 1.12 & 0.84 & 1.35 & 1.49 \\
\hline Liguria & 0.87 & 2.62 & 1.69 & 1.00 & 1.11 & 0.93 & 1.51 & 1.74 \\
\hline Rioja & 0.85 & 1.17 & 1.54 & 1.00 & 1.01 & 0.75 & 1.00 & 1.17 \\
\hline Aragón & 0.84 & 1.17 & 1.64 & 1.00 & 1.02 & 0.71 & 0.99 & 1.18 \\
\hline Emilia & 0.82 & 2.02 & 1.81 & 0.99 & 1.01 & 0.87 & 1.29 & 1.57 \\
\hline Madrid (C. de) & 0.81 & 1.20 & 1.65 & 1.00 & 0.87 & 0.85 & 0.99 & 1.22 \\
\hline Comunitat Valenciana & 0.80 & 1.00 & 1.18 & 1.01 & 1.09 & 0.86 & 0.89 & 1.12 \\
\hline Pais Vasco & 0.75 & 1.40 & 1.54 & 0.99 & 1.06 & 0.85 & 1.03 & 1.36 \\
\hline Toscana & 0.73 & 1.42 & 1.35 & 1.00 & 1.20 & 0.86 & 1.02 & 1.40 \\
\hline Asturias (P. de) & 0.73 & 1.19 & 1.36 & 1.00 & 1.25 & 0.75 & 0.93 & 1.28 \\
\hline Puglia & 0.73 & 2.18 & 2.02 & 1.13 & 0.79 & 0.96 & 1.26 & 1.73 \\
\hline Extremadura & 0.71 & 1.43 & 1.87 & 1.04 & 1.08 & 0.68 & 1.01 & 1.42 \\
\hline Veneto & 0.65 & 2.74 & 1.88 & 1.12 & 1.23 & 0.80 & 1.33 & 2.06 \\
\hline Cataluña & 0.64 & 1.26 & 1.57 & 1.03 & 1.04 & 0.83 & 0.90 & 1.40 \\
\hline Andalucía & 0.62 & 1.58 & 1.67 & 1.01 & 1.06 & 0.90 & 0.99 & 1.60 \\
\hline Castilla y León & 0.57 & 1.15 & 1.67 & 1.03 & 0.98 & 0.84 & 0.81 & 1.42 \\
\hline Castilla - La Mancha & 0.49 & 1.36 & 2.05 & 1.05 & 1.11 & 0.70 & 0.82 & 1.66 \\
\hline Molise & 0.24 & 0.53 & 1.74 & 0.98 & 0.99 & 0.88 & 0.35 & 1.50 \\
\hline Campania & 0.22 & 0.44 & 1.60 & 1.07 & 0.90 & 0.90 & 0.31 & 1.39 \\
\hline Calabria & 0.15 & 1.20 & 3.01 & 1.05 & 0.93 & 0.97 & 0.42 & 2.86 \\
\hline Sardegna & n.a. & & & & & & & \\
\hline
\end{tabular}

Source: Drawn up by the authors using data provided by the ISTAT and INE. 
The range of this series is relatively broad with a difference of 3.08 points between the first and last position. The highest values were recorded in the Canary Islands, Basilicata, Val d'Aosta, and Murcia regions (Figure 2).

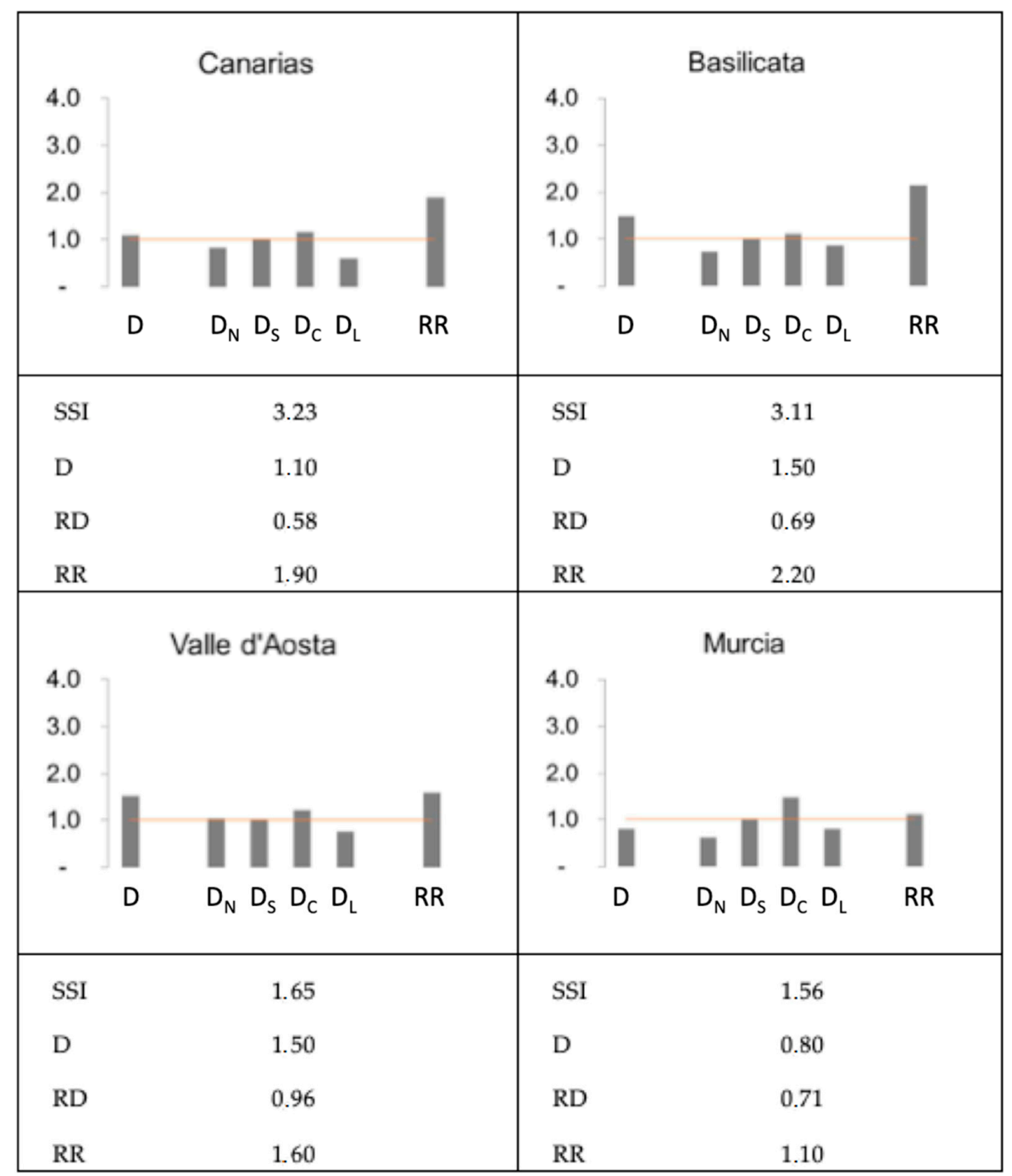

Figure 2. Regions with SSI $>1.5$. Source: Drawn up by the authors using data provided by the ISTAT and INE.

The index charting the increase in the number of facilities was not very high in any of the top four regions mentioned above (Canary Islands, Basilicata, Val d'Aosta, and Murcia), while the index measuring the increase in the average size of agritourism facilities was higher in the two Spanish regions. In Murcia, the index measuring the variation in nights spent $(D)$ was less than 1 , which reduced the even higher level of sustainability it could have achieved given the values observed for the other indices.

In general, in regions where $D>1$, the sustainability index (SSI) is greater where RD, i.e., the combination of the $D_{L}, D_{N}, D_{C}$, and $D_{S}$ indices is lower (Figure 3) and RR (the $D_{I}$ index) is higher (Figure 4). In Figure 3, the regions are arranged according to their SSI (abscissa) and RR values. Values were obtained for each of the regions examined, and a positive correlation between the two series was evident. The northern Italian regions (Lombardy, Piedmont, Valle d'Aosta, Liguria, Trentino Alto Adige, and Friuli Venezia Giulia) stand out for their medium-high sustainability values together with the Canary Islands and Basilicata, which had exceptionally high SSIs. Various southern Italian regions (Campania, Molise, and Calabria) showed much weaker performance. Most of the Spanish regions had intermediate RR and SSI values. 


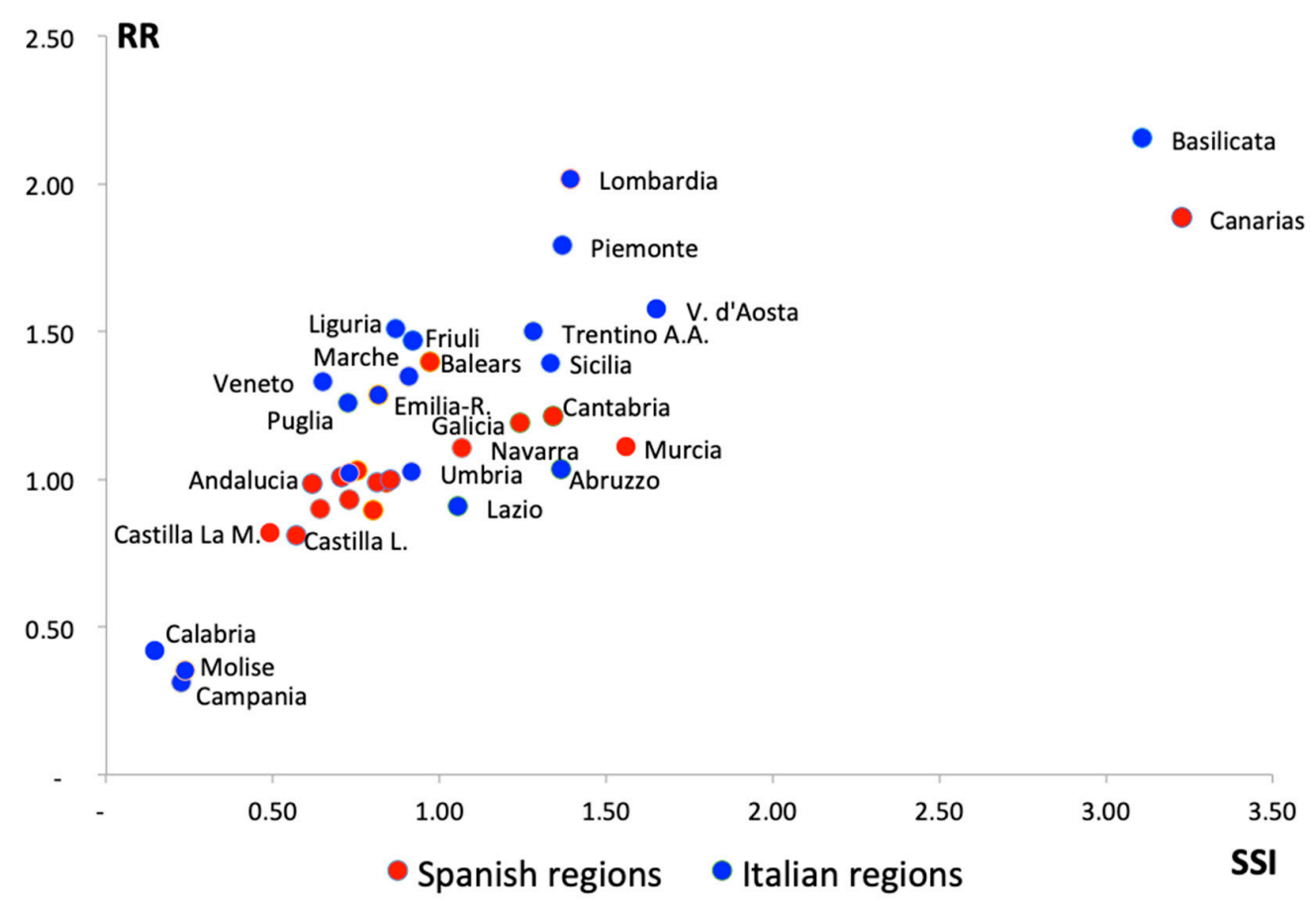

Figure 3. SSI and rural-tourism ration rate (RR) values for Spanish and Italian regions. Source: Drawn up by the authors using data provided by the ISTAT and INE.

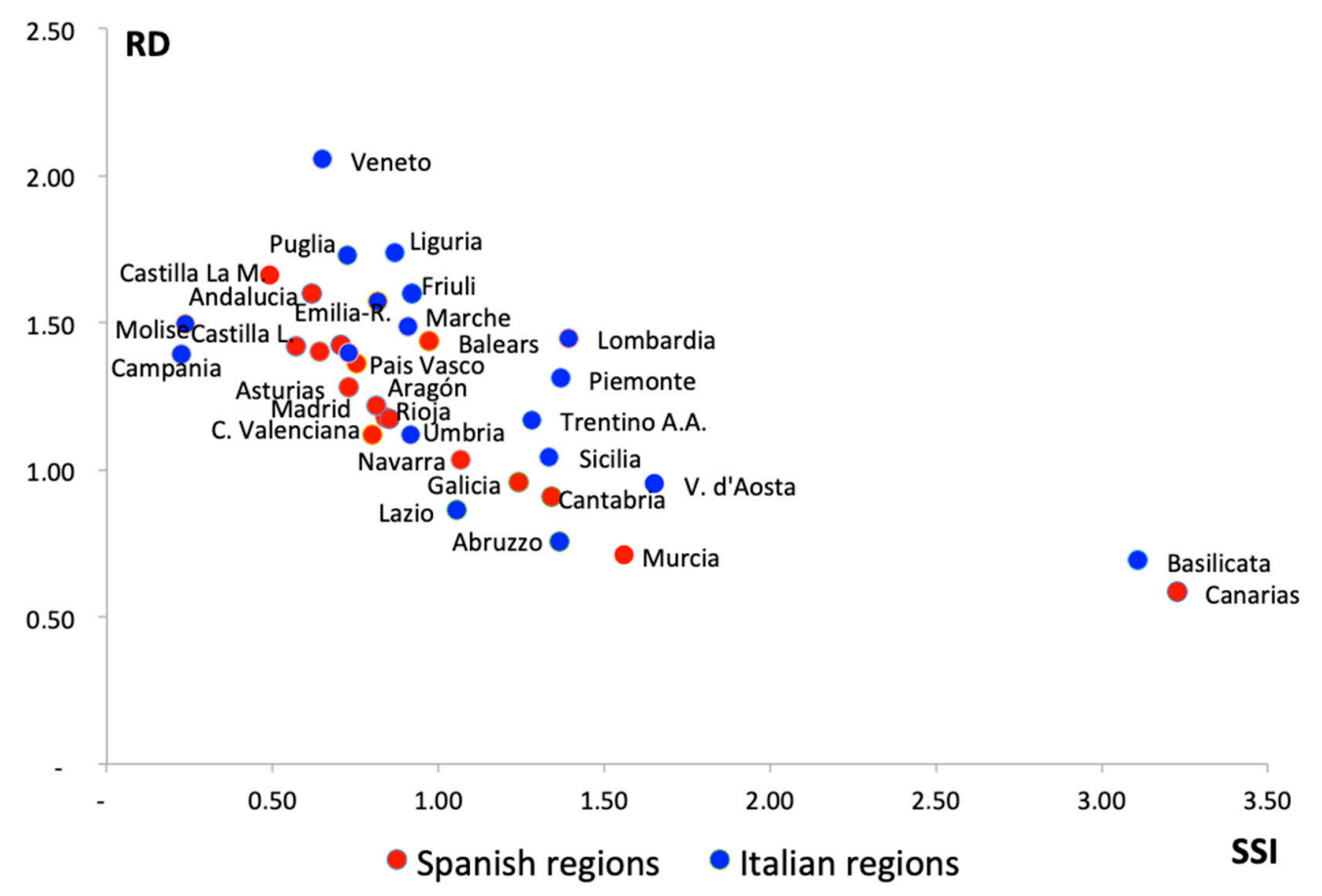

Figure 4. SSI and rural-tourism diffusion (RD) values for Spanish and Italian regions. Source: Drawn up by the authors using data provided by ISTAT and INE.

Figure 4 demonstrates the obvious inverse correlation between SSI and RD, and the good performances of Murcia, Cantabria, Galicia, and Navarra. The relatively poor position of the Veneto region is striking given that Veneto is Italy's premier tourist destination [96]. The results achieved by Basilicata and the Canary Islands are also noteworthy.

By viewing the SSI and OR values (Table 2) in context, the regional dynamics of agritourism in the two countries can be interpreted on the basis of their most significant elements, such as efficiency of use 
of the facilities. The distribution of the regions as defined by these two values can be seen in Figure 5 . Three blocks of regions with very different occupancy rates can be distinguished: very low values $(\mathrm{OR}<5)$, intermediate values $(5 \leq \mathrm{OR}<25)$, and very high values $(\mathrm{OR} \geq 25)$. The dashed vertical line distinguishes regions with SSI $>1$ from those with SSI $<1$. In the next paragraph we will try to identify homogeneous groups of regions, the specific features of which could suggest the need for regulatory guidelines and could be useful both for reducing potential problems and for encouraging good practices.

Table 2. Essential characteristics of the selected groups of regions and cases.

\begin{tabular}{|c|c|c|c|c|c|c|c|c|c|}
\hline Groups/Cases & $\begin{array}{c}\text { Nights } \\
\text { Spent } \\
5-17\end{array}$ & $\begin{array}{c}\text { Arrivals } \\
5-17\end{array}$ & $\begin{array}{c}\text { National \% } \\
\text { of Nights } \\
‘ 17\end{array}$ & $\begin{array}{c}\text { National \% } \\
\text { of Arrivals } \\
' 17\end{array}$ & $\begin{array}{c}\text { Nights } \\
\text { Spent } \\
2017\end{array}$ & $\begin{array}{c}\text { Nights } \\
\text { Spent } \\
2005\end{array}$ & $\begin{array}{c}\text { Arrivals } \\
2017\end{array}$ & $\begin{array}{c}\text { Arrivals } \\
2005\end{array}$ & $\begin{array}{c}\text { Average } \\
\text { Stay } \\
2017\end{array}$ \\
\hline Group A & -47.26 & -44.06 & 1.36 & 1.41 & 172,433 & 326,925 & 45,773 & 81,828 & 3.77 \\
\hline Group B & -14.28 & 68.17 & 1.27 & 1.85 & 161,481 & 188,374 & 59,961 & 35,654 & 2.69 \\
\hline Group C Spain & 84.38 & 109.03 & 71.70 & 74.25 & $7,879,687$ & $4,273,634$ & $2,992,152$ & $1,431,465$ & 2.63 \\
\hline Group C Italy & 93.95 & 138.89 & 60.39 & 61.29 & $7,675,364$ & $3,957,391$ & $1,987,391$ & 831,921 & 3.86 \\
\hline Group C & 88.98 & 120.00 & - & - & $15,555,051$ & $8,231,025$ & $4,979,543$ & $2,263,386$ & 3.12 \\
\hline Group D Italy & 173.86 & 218.74 & 11.08 & 16.36 & $1,408,046$ & 514,150 & 530,333 & 166,383 & 2.66 \\
\hline Group D & 80.15 & 109.07 & - & - & $3,026,260$ & $1,679,889$ & $1,206,744$ & 577,190 & 2.51 \\
\hline Balearics & 143.17 & 277.92 & 9.75 & 6.79 & $1,071,532$ & 440,657 & 273,691 & 72,421 & 3.92 \\
\hline Canaries & 20.50 & 123.18 & 3.82 & 2.17 & 419,728 & 348,313 & 87,341 & 39,134 & 4.81 \\
\hline Basilicata & 113.01 & 180.27 & 0.53 & 0.67 & 67,008 & 31,458 & 21,612 & 7711 & 3.10 \\
\hline Trentino A.A. & 101.43 & 148.45 & 24.40 & 17.36 & $3,101,456$ & $1,539,693$ & 562,844 & 226,539 & 5.51 \\
\hline
\end{tabular}

Source: Drawn up by the authors using data provided by the ISTAT and INE.

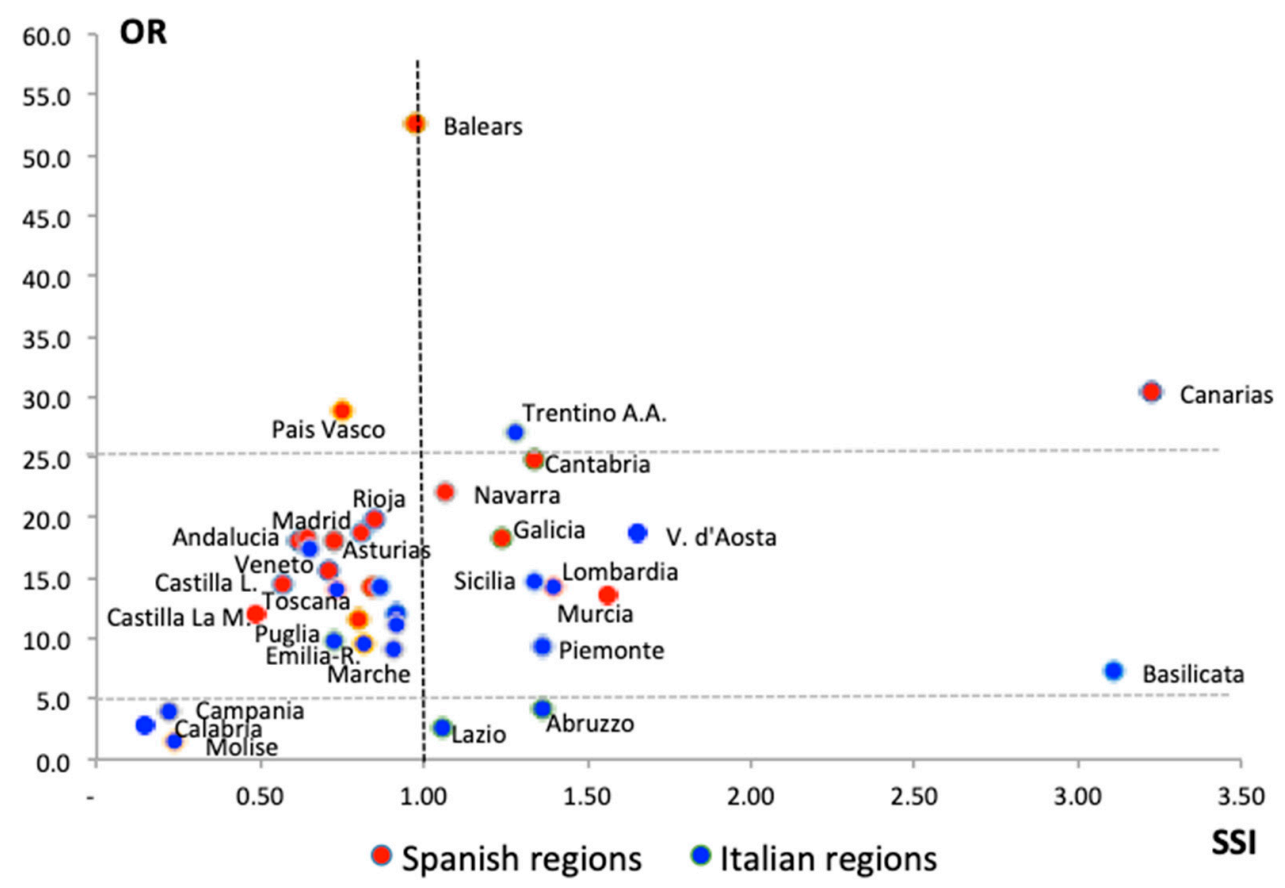

Figure 5. Sustainability index (SSI) and occupancy rate (OR) for the use of agritourism facilities. Source: Drawn up by the authors using data provided by the ISTAT and INE.

\section{Discussion}

The first group of regions (bottom left in Figure 6) contains three Italian regions (Figure 7) which have very low OR, an SSI $<1$ and little impact on the national agritourism sector. This is also the most problematic group (A, Figure 6) because, in addition to recording a significant drop in the number of nights spent by tourists in agritourism facilities, they were also affected by a decrease in arrivals 
(Table 2). This group includes Molise, Calabria, and Campania, regions in Southern Italy with very low occupancy rates and sustainability index values.

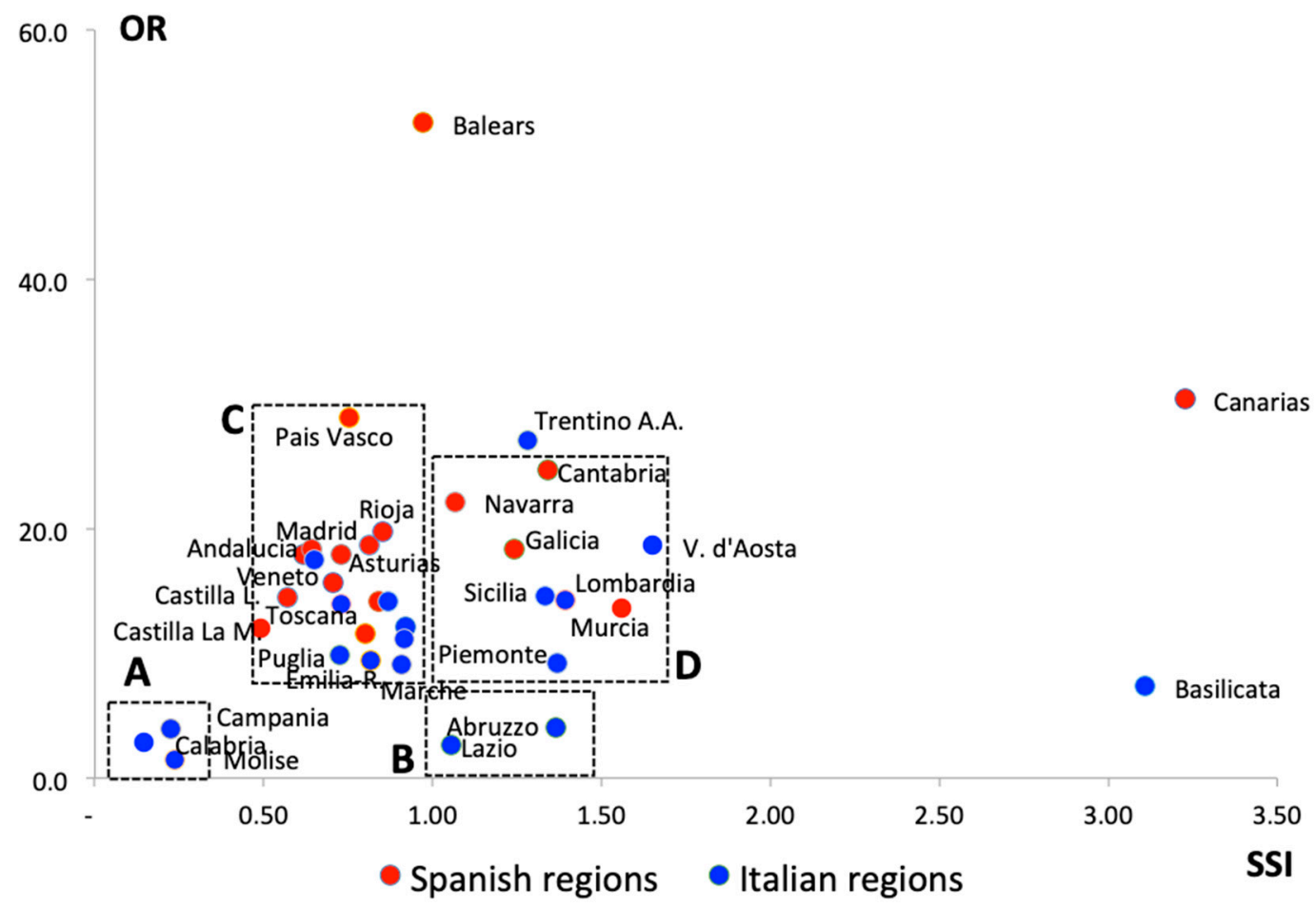

Figure 6. Sustainability index and occupancy rate of agritourism facilities: groups of regions. Source: Drawn up by the authors using data provided by the ISTAT and INE.

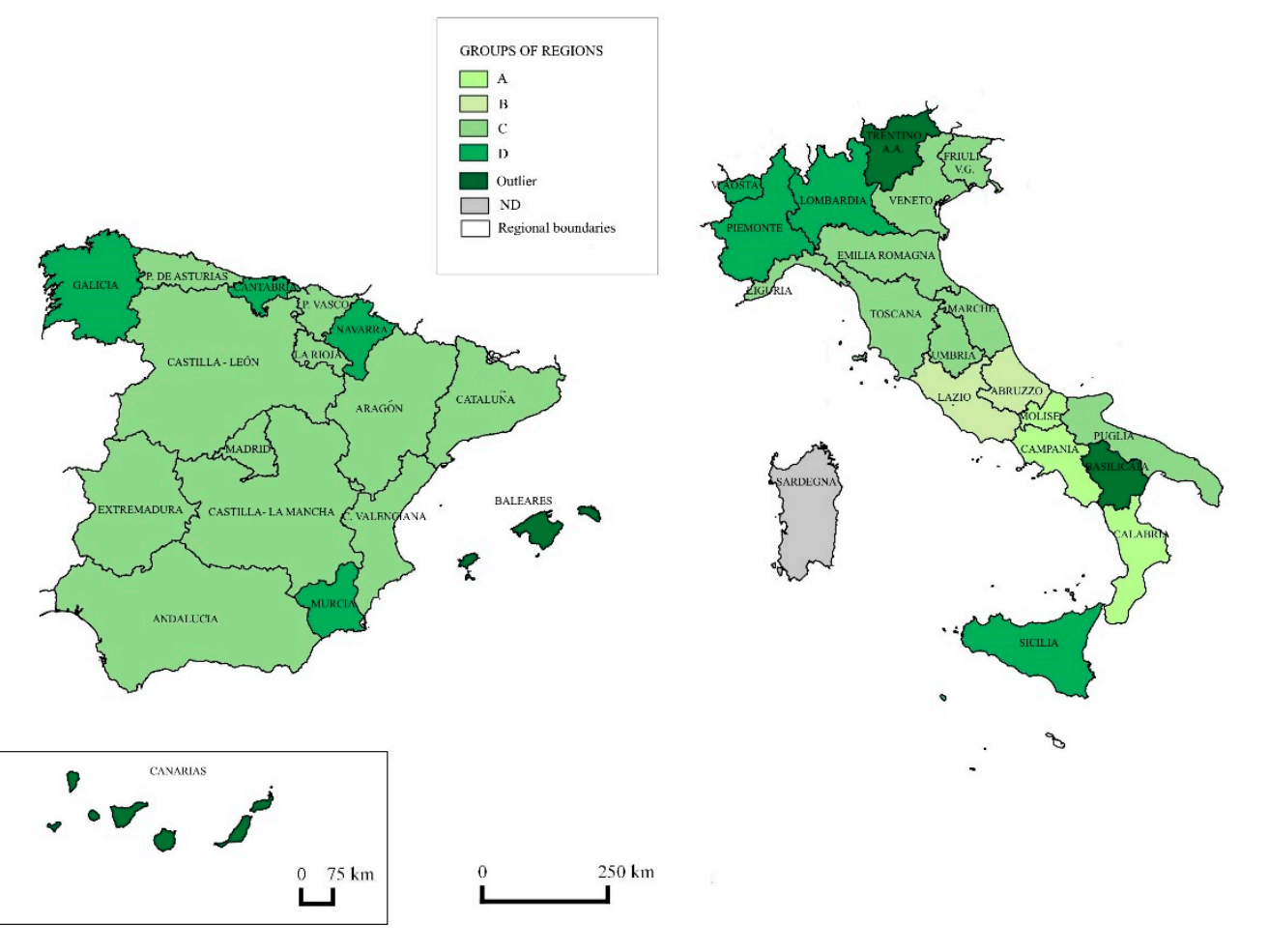

Figure 7. Groups of regions. Source: Drawn up by the authors using data provided by the ISTAT and INE (Map by Labianca M. and Navarro F.). 
Molise is a region identified with the EU "competitiveness objective." Although it has a high potential for experiential rural tourism, due to its well-known agri-food tradition derived from the millennial tradition of transhumance [97-99], it has suffered a significant drop in the number of tourists engaging in farm tourism, which has led to a fall in the occupancy rate.

Demand for agritourism has also collapsed in Campania, in terms of arrivals and in particular of nights spent. The number of agritourism facilities has, however, more than tripled, probably due to "other," as yet undefined, factors. Their gross occupancy rate, which at the beginning of the study period was far above average, collapsed at the end of the period. The sustainability index is very low and the reduction in flows is surprising, given the attractiveness of its rural areas such as the Cilento National Park.

Between 2005 and 2017, Calabria was the only member of this group of regions in which the number of nights spent in agritourism facilities increased, albeit to a more modest extent than the number of arrivals. However, these results alone cannot account for the increase in supply in terms of the number of facilities and beds, given the very low occupancy rate of the facilities at the beginning of the period (which had increased slightly by the end), even if the region's history and environmental appeal suggest that it has high growth potential for rural tourism.

Overall, the Group A regions show high potential for improving the occupancy rate in existing facilities and the sustainability of tourism through agriculture, providing that future public intervention actions focus on enhancing the natural (biodiversity) and intangible heritage (peasant culture) of these rural territories, rather than their real estate.

Abruzzo and Lazio appear to the right of the vertical dotted line in Figure 5 (bottom right). Although these two Italian regions have a low OR of $<5$ they have an SSI $>1$. They also have a very low impact on the Italian agritourism sector in terms of total numbers of visitors (Group B in Figure 6). During the period we studied, they experienced a decrease in the number of nights spent, which ensured that occupancy rates remained low (Table 2). However, their performance remained satisfactory, because arrivals increased substantially in both regions and even doubled in Lazio.

Overall, the sustainability of Group B is relatively high, as is the potential for improvement in the use of existing facilities that could be generated by an increase in the flow of visitors, which would have a favorable impact. The focus here should concentrate more on cultural attractions, which in rural areas are directly linked to the values of the natural landscape and the specific, deep-rooted food and wine traditions.

The largest group includes regions with SSI $<1$ (but always $>0.5$ ), and occupancy rates of between 5 and 25. Regions in this group include the País Vasco in Spain, which has a very high OR, but similar problems of sustainability (Group C in Figure 6). This group showed increases of almost $90 \%$ in nights spent and over $120 \%$ in arrivals (Table 2). It includes 11 Spanish regions (Figure 7) which account for a significant proportion (over 70\%) of Spanish agritourism flows. The number of nights spent in these regions (Andalucía, Aragón, Asturias, Castilla y León, Castilla-La Mancha, Cataluña, Comunitat Valenciana, Extremadura, Madrid, La Rioja, and País Vasco) grew by $84 \%$ while arrivals were up by $109 \%$. There are various possible reasons for these results. European funding (especially from the LEADER program) and support from several other public programs have helped increase the supply of rural tourism and have helped enhance natural and cultural heritage $[100,101]$, but many of the initiatives have not been based on rational business or planning criteria [102], which explains the low occupancy rates and sustainability values. The increased interest in natural, rural, and inland areas, which are far away from traditional mass tourism resorts and coastal destinations favored by Spanish domestic tourism may be another factor [75]. Tourism in these regions tends to be seasonal with the demand concentrated in the Easter holidays in the spring and in August in the summer. The quietest month is January, and many establishments close in the winter. Cultural heritage is also an important factor, as illustrated by the case of Extremadura [103]. Positively exploiting the natural heritage and the abundance of second homes (a factor that complements agritourism) can increase the number of arrivals and the nights spent in these rural areas. Finally, these values for arrivals and nights spent 
would be somewhat higher if the extensive black market in undeclared, unauthorized accommodation were taken into consideration.

The group also includes eight Italian regions (Figure 7), which have grown roughly at the same rate as the Spanish regions. They represent about $60 \%$ of the agritourism flows recorded in Italy. Four of these regions (Emilia Romagna, Tuscany, Umbria, and Marche) are central-northern regions, which traditionally are amongst the most active in agritourism, while Friuli Venezia Giulia, Veneto, and Liguria are in the north of the country. Puglia is the only region in this group in southern Italy.

Unlike the other regions in the group, Castilla y Leon, Castilla-La Mancha, and Puglia show low occupancy rates and sustainability indices, which means that any further development should focus on improving existing hospitality capacities and cultural attractions, particularly those related to agri-food, so as to diversify tourism more effectively in agricultural and rural contexts.

These regions obtained intermediate sustainability values, and in some cases, there was little potential for improving occupancy rates. The growth strategies in Group C regions should be carefully differentiated by region, and particular care must be taken in those in which a low degree of sustainability is associated with a high occupancy rate.

The group of regions with SSI $>1$ and $5<$ OR $<25$ form a much less crowded (Group D in Figure 6), albeit with very interesting results. In the period considered (2005-2017), the total number of nights spent grew by $80 \%$ while arrivals were up by $110 \%$ (Table 2). The average stay was well under three days and was thus typical of this type of tourism.

This group includes the four Spanish regions of Galicia, Cantabria, Navarra, and Murcia (which has a significantly lower occupancy rate) and the four Italian regions of Sicily in the far south, and Lombardy, Piedmont, and the Val D'Aosta in the far north, which also have lower occupancy rates (Figure 7).

The four Spanish regions in this group include about $17 \%$ of the arrivals and $15 \%$ of the nights spent at agritourism establishments in Spain, while the figures for the four Italian regions in this group were $11 \%$ and $16 \%$, respectively. The number of beds in rural tourism increased very slightly over the study period in these regions (i.e., Murcia). At the same time they also received increasing numbers of domestic tourists from the regions themselves, from other nearby regions (i.e., tourists from País Vasco going to rural areas of Navarra or Cantabria), and from all over Spain (Galicia), a fact which could explain at least in part the high levels of sustainability and stays. Additionally, the increasing popularity of these regions, as witnessed by a rise in the number of second homes, could also explain this slight increase in bed places in rural tourism during the period.

In addition to attracting consistent flows of visitors (over 250,000 arrivals in 2017), the Cantabria region of Northern Spain stands out for its fairly high sustainability index, which, combined with one of the highest occupancy rates, makes the region a potential reference for others to follow. Cantabria is a predominantly domestic tourism destination, which means that visits are more uniformly distributed over the course of the year, so reducing the seasonal factor. Families with young children make up over $50 \%$ of visitors, and they are very loyal to the region, which ensures that they recommend it to others and sometimes directly invest in it through the purchase of second homes [104]. Although Cantabria must adapt supply to meet real demand [105], from the point of view of tourism it has an important competitive margin with respect to the growing demands of nearby markets such as France [106]. From a rural tourism perspective, this can be explained by the rise in tourism activities related to its rich heritage, such as visiting cave paintings [107]. This mountainous, essentially rural region is becoming increasingly economically diversified through a combination of agricultural, industrial, and service activities that are replacing the traditionally mountain economy devastated by the modernization of farming methods in the 1950s and 1960s [108].

The Italian regions have a largely underutilized supply of agritourism establishments, but arrivals grew significantly over the study period (2005-2017), particularly in Piedmont (303\%) and Lombardy $(548 \%)$. 
Val d'Aosta also has a very high sustainability index (third overall among all the regions examined) although activity was less intense in the last year we studied (2017), when there were fewer than 7000 thousand arrivals who together spent about 40,000 nights in the area.

The regions in Group D therefore present a number of interesting characteristics and could provide appropriate models for regional development strategies in this sector. Sustainability is generally very high, combined in most cases with high potential for improving occupancy rates in the existing facilities, and is thus more consistent with the objectives of eco-effectiveness, than those of eco-efficiency.

The Balearics, the Canaries, Basilicata, and Trentino Alto Adige are each distinguished by having a leading position in a specific index (Figures 5 and 6 ) and, for this reason they are regarded as "outlier" regions (Figure 7).

The Balearic Islands alone hosts $7 \%$ of arrivals and 10\% of Spanish farm holidays and has the highest occupancy rate (over 50\%) of all the regions (Table 2). The strong specialization in seaside tourism in modern hotel accommodation could make "agritourism" more attractive for those looking for a more traditional, more "authentic" holiday, albeit closely linked to the dominant form of tourism on the islands, as suggested by the longer average length of stay (almost four days). The dominance of international tourists and the proximity of coastal resources and attractions leads to a symbiotic relationship between rural and coastal tourism and destinations in these islands, which helps to explain the impressive values in arrivals and stays [100].

Rural tourism in the Balearic Islands is focused on foreign, upper-middle class tourists, quite unlike the traditional tourist demographic [109]. Despite its novelty value and the fact that it offers an attractive alternative to standard beach resort accommodation, the high prices of the various products and services on offer are a significant competitive disadvantage, as they are much higher than on the Spanish mainland. There are also significant differences between the islands [110], with Mallorca accounting for the vast majority of rural tourism facilities $(83.9 \%)$, with Ibiza $(10 \%)$ and Menorca $(6 \%)$ trailing far behind.

The occupancy rate in the Canary Islands is about half that of the Balearics, although it grew over the period we studied, as did the average size of facilities. This archipelago has a much lower share of domestic tourists (around half a million arrivals in 2017) than the Balearic Islands, but has the highest sustainability index of all the regions. The average stay is also longer, but this may be due to its greater distance from the points of origin of most of the visitors. These positive values could also be explained by the fact that, as in the Balearic Islands, rural tourism destinations can also be used as a base for coastal tourism. Although mass beach tourism is still the core business, a change of direction has been observed since the 1990s [111], due to the increase in demand for "authentic" experiences perceived as related to nature and to a lesser extent to local culture, a niche into which agritourism fits perfectly [112]. Again, as in the Balearic Islands, the potential of each island is enhanced by its own unique features, which are reinforced by their geographical 'isolation.' El Hierro, which has made a strong commitment to the Sustainable Development of the tourism sector with the help of LEADER, is a case in point, and agritourism has become the most important [113], strategy for developing sustainable tourism on the island of La Palma, especially since the declaration of the whole island as a Biosphere Reserve in 2002 [114].

Basilicata was recently included in the EU Competitiveness Objective, due to the discovery and subsequent exploitation of significant oil reserves. This has led to rapid growth in regional GDP in what is a predominantly rural and still socially fragile area. Despite being associated with the Competitiveness Objective, Basilicata retains all the ecological and economic issues typically found in regions with development problems. On the positive side, over the last twenty years it has recorded a high level of growth in cultural tourism, with the historic center of Matera (one of the region's two capital cities) as its main attraction. This was declared an area of cultural heritage as it has been continuously inhabited since the Paleolithic period. The city was designated the European Capital of Culture for 2019. 
The particularly high value of the Basilicata SSI (3.11) stems, as in the previous case, from a more consistent increase in arrivals $(+180 \%)$ than in nights spent $(+113 \%)$, which means that visitors are staying for shorter average stays. The high SSI is, however, accompanied by a low occupancy rate, which in 2017 manifested itself in just over 20,000 arrivals, thus reducing the importance of the region in terms of the agritourism sector as a whole.

Trentino Alto Adige has many similarities with the regions in Group D: a high sustainability index and a very high occupancy rate (fourth overall). It has also enjoyed a significant increase in nights spent and particularly in arrivals (2005-2017). However, perhaps the most impressive statistic is the exceptional volume of visitors: in 2017 it had over half a million arrivals and over 3 million nights spent, which represent $17 \%$ and $24 \%$ of the national total, respectively. The average stay was very high at around six days, much longer than the normal stay for agritourism. This may be due to visitors using the accommodation for winter skiing weeks and more traditional summer holidays, rather than for experiential breaks. These kinds of visitors can also make an important contribution to rural economies and can be attracted for example via campaigns aimed at improving the quality and range of the food offered to tourists.

\section{Conclusions}

Agritourism is considered one of the main forms of economic diversification for the regeneration of rural areas. However, its sustainability is a complex issue which has ramifications that go beyond just physical and environmental sustainability.

There are many potential benefits of the diversification of agriculture through tourism, but as highlighted above (Section 2), undesirable results or side effects can often occur, sometimes directly contradicting the aims of the policies and the objectives of local stakeholders.

In this study we propose a Synthetic Sustainability Index (SSI) aimed at evaluating the eco-effectiveness of the evolutionary dynamics of agritourism. The index was constructed by identifying proxies for the ecological, economic, social, and institutional dimensions of sustainability and has been tested in Italian and Spanish regions, in which agritourism plays an important role in rural development processes.

The results confirm that there is a sustainability problem associated with the uncontrolled growth of agritourism, fueled by policies that have repeatedly encouraged farms to diversify in this way, particularly in the last two programming cycles of European funding. The justification for these policies is not only economic, but also environmental and sometimes social, as they seek to improve farm incomes by promoting less intensive agricultural practices, which are often associated with ecosystem services (biodiversity, landscape, carbon cycle control, etc.). Agritourism enables better use of endogenous resources in the most fragile rural areas, and particularly of the agricultural workforce, both through the recovery and capitalization of tacit knowledge and through the leverage provided by the higher qualifications and skills acquired by young people, which can encourage them to stay in regions plagued by problems of declining or aging populations.

Policies of this kind have often produced interesting and significant effects in certain territories, both for businesses and in terms of the many dimensions that characterize sustainability, as explained above. However, the overall effects on a regional scale have not always been satisfactory. The regions have often underestimated the mutual effects of the various components of the sustainability process and in some cases this interaction has had unexpected negative effects, as shown by the Synthetic Sustainability Index (SSI) values.

The SSI has revealed the lack of regional homogeneity within the same country, and has enabled us to compare this phenomenon on an international scale. On the basis of their SSI and OR values, the regions were assigned to groups that constitute a reliable proxy for the ability to optimize the use of accommodation facilities. The analysis of these groups of regions confirm that the poor sustainability of agritourism in some regions of southern Italy (Group A), as noted in a previous study [94] is more widespread, albeit to a lesser degree, both within Italy and in similar European contexts. The poor 
sustainability of agritourism growth was also found in a large proportion of the central and eastern regions of Spain, the largest group of regions in Spain (Group C), and is comparable with that of Italy.

Some policymakers may have increasingly and uncritically invested in the "utilities" of agritourism, more due to superficial rhetoric [47,115-119] than out of any meaningful concern for sustainability $[29,40,120,121]$. In this situation, the SSI offers new parameters for evaluating the status quo and for drafting policies aimed at diversifying agriculture through tourism. It also provides useful guidance for changing or reformulating rural development strategies.

The application of SSI also revealed that some Italian regions, despite obtaining acceptable sustainability index values, have poor optimization and use of facilities (Group B), and therefore face a different set of problems. The solutions may lie in actions aimed exclusively at increasing arrivals, or numbers of tourists. In Group D, the values obtained for sustainability and efficiency offer positive results for a small number of Italian and Spanish regions, which for a variety of reasons have been able to attract tourist flows that are independent from other forms of tourism. Impressive results were obtained by the Italian regions of Basilicata and Trentino Alto Adige, located respectively in the south and north of the country, and by the two Spanish island regions, the Balearic and Canary Islands, which provides various insights into general good practices that could be applied in other regions.

This study has shown that many of the sustainability measures envisaged in rural development policies do not contribute effectively to achieving this goal. In fact, most of these policies centered on eco-efficiency issues that reflected the interests of the businesses involved (renewable energy, water saving), while neglecting the overall effects in terms of territorial sustainability. For this reason, the SSI values calculated in many of the regions are unsatisfactory.

Future evaluation of the effects of agritourism policies could be improved by using the tool proposed in this study. Sustainable growth strategies that measure and take into account the size and number of facilities and the number of tourists using them could be drawn up on the basis of the evidence provided by the SSI, in line with the eco-effectiveness principles of the IRT approach.

Looking towards the future and taking into account the results of this research, it would be useful to find out how this tool for assessing agritourism could be usefully integrated into other indices and indicators that offer a more general assessment of the impact of tourism on destinations. This would facilitate the effective use of sustainable tourism indicators as planning tools. It would also be interesting to extend the evaluation and comparison to the rest of Europe, given that a knowledge of the situation at a regional and community scale is crucial for establishing sustainable growth targets in this sector. In short, the instrument proposed here could contribute to the evaluation and comparison of the regional impact of agritourism, and could suggest policies and strategies based on genuinely sustainable objectives, thus providing potential support for the process of transition from a linear to a circular economy.

Author Contributions: Conceptualization, A.B. and S.D.R.; methodology, A.B. and S.D.R.; formal analysis, A.B. and S.D.R.; data curation, A.B. and E.C.G.; cartography, M.L. and F.N.V.; writing-original draft preparation, A.B. and S.D.R.; writing-review and editing A.B., E.C.G., F.N.V., M.L. and S.D.R.; supervision, A.B. and S.D.R. All authors have read and agreed to the published version of the manuscript.

Funding: This research received no external funding.

Acknowledgments: The authors are grateful to the anonymous reviewers for their valuable suggestions and comments.

Conflicts of Interest: The authors declare no conflict of interest.

\section{References}

1. Khanal, A.R.; Honey, U.; Omobitan, O. Diversification through "fun in the farm": Analyzing structural factors affecting agritourism in Tennessee. Int. Food Agribus. Manag. Rev. 2020, 23, 105-120. [CrossRef]

2. Khanal, A.R.; Mishra, A.K. Agritourism and off-farm work: Survival strategies for small farms. Agric. Econ. 2014, 45, 65-76. [CrossRef] 
3. Sonnino, R. For a "piece of bread"? Interpreting sustainable development through agritourism in Southern Tuscany. Sociol. Rural. 2004, 44, 285-300. [CrossRef]

4. Arru, B.; Furesi, R.; Madau, F.A.; Pulina, P. Recreational Services Provision and Farm Diversification: A Technical Efficiency Analysis on Italian Agritourism. Agriculture 2019, 9, 42. [CrossRef]

5. Flanigan, S.; Blackstock, K.; Hunter, C. Agritourism from the perspective of providers and visitors: A typology-based study. Tour. Manag. 2014, 40, 394-405. [CrossRef]

6. Phillip, S.; Hunter, C.; Blackstock, K. A typology for defining agritourism. Tour. Manag. 2010, 31, 754-758. [CrossRef]

7. Oostindië, H.; van der Ploeg, J.D.; Broekhuizen, R.V.; Ventura, F.; Milone, P. The central role of nested markets in rural development in Europe. Riv. Econ. Agrar. 2010, 65, 191-224.

8. Van der Ploeg, J.D. Newly emerging, nested market: A theoretical introduction. In Rural Development and the Construction of New Markets; Hebinck, P., Schneider, S., Van der Ploeg, J.D., Eds.; Routledge: London, UK, 2011. [CrossRef]

9. Ventura, F.; Schiavelli, A.; Milone, P. Direct Food Roma; Saggine Donzelli: Roma, Italy, 2016.

10. Lumsdon, L.M.; McGrath, P. Developing a conceptual framework for slow travel: A grounded theory approach. J. Sustain. Tour. 2011, 19, 265-279. [CrossRef]

11. Serdane, Z.; Maccarrone-Eaglen, A.; Sharifi, S. Conceptualising slow tourism: A perspective from Latvia. Tour. Recreat. Res. 2020, 21, 337-350. [CrossRef]

12. Van der Ploeg, J.D.; Roep, D. Multifunctionality and rural development: The actual situation in Europe. In Multifunctional Agriculture. A New Paradigm for European Agriculture and Rural Development; van Huylenbroeck, G., Durand, G., Eds.; Ashgate: Hampshire, UK, 2003; pp. 37-53.

13. Alario, M.; Morales, E. Iniciativas de las mujeres: Emprendimiento y oportunidades en el espacio rural de Castilla y León. Doc. d'Anàlisi Geogràfica 2016, 62, 613-637. [CrossRef]

14. Maroto-Martos, J.C.; Voth, A.; Pinos-Navarrete, A. The Importance of Tourism in Rural Development in Spain and Germany. In Neoendogenous Development in European Rural Areas. Results and Lessons; Cejudo, E., Navarro, F., Eds.; Springer: Cham, Switzerland, 2020; pp. 181-205.

15. Potočnik-Slavič, I.; Schmitz, S. Farm tourism across Europe. Eur. Countrys. 2013, 5, 265-274. [CrossRef]

16. Navarro, F.; Labianca, M.; Cejudo, E.; De Rubertis, S.; Salento, A.; Maroto, J.C.; Belliggiano, A. Interpretations of innovation in rural development. The cases of Leader projects in Lecce (Italy) and Granada (Spain) in 2007-2013 period. Eur. Countrys. 2018, 10, 107-126. [CrossRef]

17. Nieto Masot, A.; Cárdenas Alonso, G.C. 25 Years of the leader initiative as European Rural Development Policy: The case of Extremadura (SW Spain). Eur. Countrys. 2017, 9, 302-316. [CrossRef]

18. Streifeneder, T.; Dax, T. Agritourism in Europe: Enabling Factors and Current Developments of Sustainable On-Farm Tourism in Rural Areas. In Global Opportunities and Challenges for Rural and Mountain Tourism; Kala, D., Bagri, S.C., Eds.; IGI Globa: Hershey, PA, USA, 2020; pp. 40-58.

19. Belliggiano, A.; Sturla, A.; Vassallo, M.; Viganò, L. Neo-Endogenous Rural Development in Favor of Organic Farming: Two Case Studies from Italian Fragile Areas. Eur. Countrys. 2020, 12, 1-29. [CrossRef]

20. Labianca, M.; De Rubertis, S.; Belliggiano, A.; Salento, A.; Navarro, F. Social Innovation, Territorial Capital and LEADER Experiences in Andalusia (Spain) and in Molise (Italy). In Neoendogenous Development in European Rural Areas. Results and Lessons; Cejudo, E., Navarro, F., Eds.; Springer: Cham, Switzerland, 2020; pp. 111-131.

21. Hashemkhani Zolfani, S.; Sedaghat, M.; Maknoon, R.; Zavadskas, E.K. Sustainable tourism: A comprehensive literature review on frameworks and applications. Econ. Res.-Ekon. Istraživanja 2015, 28, 1-30. [CrossRef]

22. Mastronardi, L.; Giaccio, V.; Giannelli Scardera, A. Is agritourism eco-friendly? A comparison between agritourisms and other farms in Italy using farm accountancy data network dataset. SpringerPlus 2015, 4, 590. [CrossRef] [PubMed]

23. Lupi, C.; Giaccio, V.; Mastronardi, L.; Giannelli, A.; Scardera, A. Exploring the features of agritourism and its contribution to rural development in Italy. Land Use Policy 2017, 64, 383-390. [CrossRef]

24. Marsh, J. An index of tourism sustainability. In Tourism and Sustainable Development: Monitoring, Planning, Managing; Nelson, J., Butler, R., Wall, G., Eds.; Department of Geography, University of Waterloo: Waterloo, ON, Canada, 1993; pp. 257-258. 
25. Nelson, J.G. Are tourism growth and sustainability objectives compatible? Civil, assessment, informed choice. In Tourism and Sustainable Development: Monitoring, Planning, Managing; Nelson, J., Butler, R., Wall, G., Eds.; Department of Geography, University of Waterloo: Waterloo, ON, Canada, 1993; pp. 259-268.

26. Payne, R.J. Sustainable tourism: Suggested indicators and monitoring techniques. In Tourism and Sustainable Development: Monitoring, Planning, Managing; Nelson, J., Butler, R., Wall, G., Eds.; Department of Geography, University of Waterloo: Waterloo, ON, Canada, 1993; pp. 249-254.

27. Manning, T. Indicators of tourism sustainability. Tour. Manag. 1999, 20, 179-181.

28. James, D. Local sustainable tourism indicator. In Proceedings of the 5th International Forum on Tourism Statistics, Caledonian University Conference Proceeding, Glasgow, UK, 19-23 June 2000.

29. Miller, G. The development of indicators for sustainable tourism: Results of a Delphi survey of tourism researchers. Tour. Manag. 2001, 22, 351-362. [CrossRef]

30. Sirakaya, E.; Jamal, T.B.; Choy, H.S. Developing indicators for destination sustainability. In The Encyclopedia of Ecotourism; Weaver, D.B., Ed.; CAB International: Wallingford, UK, 2001; pp. 411-432.

31. Twining-Ward, L.; Butler, R. Implementing sustainable tourism development on a small island: Development and use of sustainable tourism development indicators in Samoa. J. Sustain. Tour. 2002, 10, 363-387. [CrossRef]

32. Dwyer, L.; Kim, C. Destination competitiveness: Determinants and indicators. Curr. Issues Tour. 2003, 6, 369-414. [CrossRef]

33. Vera, J.F.; Ivars, J.A. Measuring sustainability in a mass tourist destination: Pressures, perceptions and policy responses in Torrevieja, Spain. J. Sustain. Tour. 2003, 11, 181-203.

34. Bloyer, J.; Gustke, L.; Leung, Y. Indicators for sustainable tourism development: Crossing the divide from definition to actions. In Sustainable Tourism; Pineda, F., Brebbia, C., Múgica, M., Eds.; WiT: Southampton, UK, 2004; pp. 109-115.

35. Blackstock, K.L.; McCrum, G.; Scott, A.; White, V. A Framework for Developing Indicators of Sustainable Tourism; Macaulay Institute: Aberdeen, UK, 2006.

36. Choi, H.C.; Sirakaya, E. Sustainability indicators for managing community tourism. Tour. Manag. 2005, 27, 1274-1289. [CrossRef]

37. White, V.; McCrum, G.; Blackstock, K.L.; Scott, A. Indicators and Sustainable Tourism: Literature Review; Macaulay Institute: Aberdeen, UK, 2006.

38. Sancho, A.; García, G.; Rozo, E. Comparativa de indicadores de sostenibilidad para destinos desarrollados, en desarrollo y con poblaciones vulnerables. Ann. Tour. Res. 2007, 9, 150-177.

39. Schianetz, K.; Kavanagh, L. Sustainability indicators for tourism destinations: A complex adaptive systems approach using systemic indicator systems. J. Sustain. Tour. 2008, 16, 601-628. [CrossRef]

40. Pulido, J.; Sánchez, M. Measuring tourism sustainability: Proposal for a composite index. Tour. Econ. 2009, 15, 277-296.

41. Blancas, F.J.; Lozano-Oyola, M.; González, M.; Guerrero, F.M.; Caballero, R. How to use sustainability indicators for tourism planning: The case of rural tourism in Andalusia (Spain). Sci. Total Environ. 2011, 412, 28-45. [CrossRef]

42. Asmelash, A.G.; Kumarc, S. Assessing progress of tourism sustainability: Developing and validating sustainability indicators. Tour. Manag. 2019, 71, 67-83. [CrossRef]

43. Torres-Delgado, A.; Saarinenc, J. Using indicators to assess sustainable tourism development: A review. Tour. Geogr. Int. J. Tour. Space Place Environ. 2014, 16, 31-47. [CrossRef]

44. Ko, T.G. Development of a tourism sustainability assessment procedure: A conceptual approach. Tour. Manag. 2005, 26, 431-445. [CrossRef]

45. Villanueva-Álvaro, J.J.; Mondéjar-Jiménez, J.; Sáez-Martínez, F.J. Rural Tourism: Development, Management and Sustainability in Rural Establishments. Sustainability 2017, 9, 818. [CrossRef]

46. Marzo-Navarro, S.; Pedraja-Iglesias, M.; Vinzón, L. Sustainability indicators of rural tourism from the perspective of the residents. Tour. Geogr. Int. J. Tourism Space Place Environ. 2015, 17, 586-602. [CrossRef]

47. Park, D.B.; Yoon, Y.S. Developing Sustainable Rural Tourism. Evaluation Indicators. Int. J. Tour. Res. 2011, 13, 401-415. [CrossRef]

48. EC-European Commission. The European Tourism Indicator System. ETIS Toolkit for Sustainable Destination Management; European Union: Luxembourg, 2016. 
49. WTO-World Tourism Organization. Indicators of Sustainable Development for Tourism Destinations: A Guidebook; World Tourism Organization: Madrid, Spain, 2004.

50. Braungart, M.; McDonough, W.; Bollinger, A. Cradle-to-cradle design: Creating healthy emissions-a strategy for eco-effective product and system design. J. Clean. Prod. 2007, 15, 1337-1348. [CrossRef]

51. Young, W.; Tilley, F. Can businesses move beyond efficiency? The shift toward effectiveness and equity in the corporate sustainability debate. Bus. Strat. Environ. 2006, 15, 402-415. [CrossRef]

52. Baležentis, T.; Kriščiukaitiene, I.; Baležentis, A.; Garland, R. Rural tourism development in Lithuania (2003-2010)—A quantitative analysis. Tour. Manag. Perspect. 2012, 2, 1-6. [CrossRef]

53. European Economic Community. The Future of Rural Society; Bulletin of the European Communities; COM88(501); Office for Official Publications of the European Communities: Luxembourg, 1988; pp. 1-68.

54. Henke, R.; Salvioni, C. La multifunzionalità in agricoltura: Dal post-produttivismo all'azienda rurale. In Agricoltura Multifunzionale; Aguglia, L., Henke, R., Salvioni, C., Eds.; ESI: Napoli, Italy, 2008; pp. 15-29.

55. Saxena, G.; Clark, G.; Oliver, T.; Ilbery, B. Conceptualizing integrated rural tourism. Tour. Geogr. 2007, 9, 347-370. [CrossRef]

56. Belliggiano, A. Il turismo "cult-rurale" nei processi di sviluppo locale: Evidenze e prospettive in alcune regioni meridionali. In Il Turismo Culturale Europeo; Garibaldi, R., Ed.; Franco Angeli: Milano, Italy, 2012; pp. 176-189.

57. Castillo, J.; Martínez, C. El patrimonio agrario: Definición, caracterización y representatividad en el ámbito de la UNESCO. Boletín Asoc. Española Geogr. 2014, 66, 105-124. [CrossRef]

58. Cejudo, E.; Toro, F.; Castillo, J. Agrarian Heritage as an Example of the Sustainable and Dynamic Use of Natural Resources. LEADER Projects in Andalusia 2007-2013. In Neoendogenous Development in European Rural Areas. Results and Lessons; Cejudo, E., Navarro, F., Eds.; Springer: Cham, Switzerland, 2020; pp. 251-282.

59. Courtney, P.; Hill, G.; Roberts, D. The role of natural heritage in rural development: An analysis of economic linkages in Scotland. J. Rural Stud. 2006, 22, 469-484. [CrossRef]

60. Hernández-Mogollón, J.; Campón-Cerro, A.; Leco-Berrocal, F.; Pérez-Díaz, A. Agricultural diversification and the sustainability of agricultural systems: Possibilites for the development of agrotourism. Environ. Eng. Manag. J. 2011, 10, 1911-1921. [CrossRef]

61. LaPan, C.; Barbieri, C. The role of agritourism in heritage preservation. Curr. Issues Tour. 2014, 17, 666-673. [CrossRef]

62. Plaza, J.J.; Cañizares, M.C.; Ruiz, A.R. Heritage, vineyard and tourism: Specific resources to innovate the territorial development of Castilla-La Mancha. Cuad. Tur. 2017, 40, 719-722.

63. Baraja, E.; Herrero, D.; Martínez, M.; Plaza, J.I. Turismo y desarrollo vitivinícola en espacios de montaña con "alta densidad patrimonial". Cuad. Tur. 2019, 43, 97-122. [CrossRef]

64. Agüera, F.O.; Cuadra, S.M.; López-Guzmán, T.; Morales, P.C. Study of demand on the olive-oil tourism. Case of Andalusia. Cuad. Tur. 2017, 39, 677-680.

65. Molinero, F.; Tort, J. Paisajes Patrimoniales de España; III tomos; Ministerio de Agricultura, Pesca y Alimentación, Ministerio para la Transición Ecológica; UAM ediciones: Madrid, Spain, 2018.

66. Cejudo, E.; Castillo, J. La Vega de Granada. La construcción patrimonial de un espacio agrario. In Los Regadios Históricos Españoles. Paisajes Culturales, Paisajes Sostenibles; Hermosilla, J., Ed.; Ministerio de Medio Ambiente y Medio Rural y Marino: Valencia, Spain, 2010; pp. 243-284.

67. Canales, G.; López, A. La palmera en el paisaje de huerta del Bajo Segura. Un elemento identitario necesitado de protección. E-rph Rev. Electrónica Patrim. Histórico 2013, 13, 4-39.

68. Silva, R.; Fernández, V. Claves para el reconocimiento de la dehesa como "paisaje cultural" de Unesco. An. Geogr. Univ. Complut. 2015, 35, 121-142.

69. Camarero, L. Los patrimonios de la despoblación: La diversidad del vacío. Revista PH 2019, 98, 50-69. [CrossRef]

70. Cohen, E.; Cohen, S.A. Authentication: Hot and Cool. Ann. Tour. Res. 2012, 39, 1295-1314. [CrossRef]

71. Khanom, S.; Moyle, B.; Scott, N.; Kennelly, M. Host-guest authentication of intangible cultural heritage: A literature review and conceptual model. J. Herit. Tour. 2019, 14, 396-408. [CrossRef]

72. Reeder, R.J.; Brown, D.M. Recreation, Tourism and Rural Well-Being; Economic Research Service Report; US Department of Agriculture: Washington, DC, USA, 2005.

73. Borrello, M.; Pascucci, S.; Cembalo, L. Three Propositions to Unify Circular Economy Research: A Review. Sustainability 2020, 12, 4069. [CrossRef] 
74. Pearce, D.W.; Markandya, A.; Barbier, E.B. Blueprint for a Green Economy; Earthscan Routledge: London, UK, 1989.

75. Varela, C.; Martín, F. Problemas de sostenibilidad del turismo rural en España. An. Geogr. Univ. Complut. 2011, 31, 171-194.

76. Spangenberg, J.H. Environmental space and the prism of sustainability: Frameworks for indicators measuring sustainable development. Ecol. Indic. 2002, 2, 295-309. [CrossRef]

77. Spangenberg, J.H. Reconciling sustainability and growth: Criteria, indicators, policies. Sustain. Dev. 2004, 12, 74-86. [CrossRef]

78. Spangenberg, J.H. Economic sustainability of the economy: Concepts and indicators. Int. J. Sustain. Dev. 2005, 8, 47-64. [CrossRef]

79. Pfahl, S. Institutional sustainability. Int. J. Sustain. Dev. 2005, 8, 80-96. [CrossRef]

80. Hollander, M.C.D.; Bakker, C.A.; Hultink, E.J. Product Design in a Circular Economy: Development of a Typology of Key Concepts and Terms. J. Ind. Ecol. 2017, 21, 517-525. [CrossRef]

81. Bocken, N.; De Pauw, I.; Bakker, C.; Van Der Grinten, B. Product design and business model strategies for a circular economy. J. Ind. Prod. Eng. 2016, 33, 308-320. [CrossRef]

82. Yubero, C.; García Hernández, M. El turismo en el medio rural en España desde el enfoque de la transferencia de políticas públicas. Boletín Asoc. Geogr. Española 2019, 81,1-34. [CrossRef]

83. Red Rural Nacional. LEADER en España (1991-2011). Una Contribución Activa al Desarrollo Rural; Ministerio de Medio Ambiente y Medio Rural y Marino: Madrid, Spain, 2011. Available online: https://www.mapa.gob.es/es/desarrollo-rural/publicaciones/publicaciones-de-desarrollo-rural/IN FORME\%20LEADER_tcm30-131208.pdf (accessed on 21 May 2020).

84. Di Napoli, R. Il Leader, primo laboratorio di collegamento tra turismo e agricoltura. In "I Love Turismo Rurale"; Rete Rurale Nazionale: Roma, Italy, 2019; pp. 24-26.

85. Lanzalaco, L. Innovare le istituzioni: Percorsi di sviluppo sostenibili. In Innovazione e Sostenibilità. Modelli Locali di Sviluppo al Bivio; Messina, P., Ed.; CLEUP: Padova, Italy, 2009; pp. 177-190.

86. Canoves, G.; Villarino, M.; Herrera, L. Políticas públicas, turismo rural y sostenibilidad: Difícil equilibrio. Boletín Asoc. Geógrafos Españoles 2006, 41, 199-217.

87. Tirado, J.G.; Hernández, M. Assessing the Impact of EU Rural Development Programs on Tourism. Tour. Plan. Dev. 2017, 14, 149-166. [CrossRef]

88. Tirado, J.G.; Hernández, M. Promoting tourism through the EU LEADER programme: Understanding Local Action Group governance. Eur. Plan. Stud. 2019, 27, 396-414. [CrossRef]

89. Ohe, Y.; Kurihara, S. Evaluating the complementary relationship between local brand farm products and rural tourism: Evidence from Japan. Tour. Manag. 2013, 35, 278-283. [CrossRef]

90. Szlanyinka, E. The role of cultural values in rural development. In Traditional Food Production and Rural Sustainable Development; Vaz, T., Nijkamp, P., Rastoin, J.-L., Eds.; Ashgate: Farnham, UK, 2010; pp. 101-118.

91. Belliggiano, A.; Cejudo, E.; De Rubertis, S. The Role of Agriculture in Rural Development in Spain and Italy Within the Framework of the LEADER 2007-2013 Programming Period. In Neoendogenous Development in European Rural Areas. Results and Lessons; Cejudo, E., Navarro, F., Eds.; Springer: Cham, Switzerland, 2020; pp. 149-180.

92. ISMEA. Multifunzionalità Agricola e Agriturismo. Scenario e Prospettive; ISMEA: Roma, Italy, 2017.

93. Ang, B.W.; Wang, H. Index decomposition analysis with multidimensional and multilevel energy data. Energy Econ. 2015, 51, 67-76. [CrossRef]

94. Belliggiano, A.; De Rubertis, S. El "farm tourism" como oportunidad de desarrollo sostenible en las regiones del sur de Italia. Pampa Rev. Interuniv. Estud. Territ. 2016, 13, 11-30. [CrossRef]

95. Ang, B.W. The LMDI approach to decomposition analysis: A practical guide. Energy Policy 2005, 33, 867-871. [CrossRef]

96. Istat. Le Aziende Agrituristiche in Italia 2018; Statistiche Report; Istituto Nazionale di Statistica: Roma, Italy, 2019.

97. Ballacchino, K.; Bindi, L. Cammini di Uomini, Cammini di Animali. Transumanze, Pastoralismi e Patrimoni Bioculturali; Il Bene Comune Edizioni: Campobasso, Italy, 2017. 
98. Ievoli, C.; Basile, R.G.; Belliggiano, A. The spatial patterns of dairy farming in Molise. Eur. Countrys. 2017, 9, 729-745. [CrossRef]

99. De Rubertis, S.; Belliggiano, A.; Labianca, M. Partecipazione e identità territoriale. Il caso di Castel del Giudice (Molise). Geotema 2018, 56, 48-54.

100. Jurado, J.M.; Pazos-García, F.J. Población y turismo rural en territorios de baja densidad demográfica en España. Boletín Asoc. Geógrafos Españoles 2016, 71, 247-272.

101. Canoves, G.; Villarino, M. Turismo rural en España: Paisajes y usuarios, nuevos usos y nuevas visions. Cuad. Tur. 2005, 15, 63-76.

102. Pulido, J.I.; Cárdenas, P. El turismo rural en España. Orientaciones estratégicas para una tipología aún en desarrollo. Boletín Asoc. Geógrafos Españoles 2011, 56, 155-176.

103. Sánchez Martín, J.M.; Martín Delgado, L.M.; Rengifo Gallego, J.I. La reputación online de los alojamientos rurales en Extremadura desde una óptica geoestadística. Boletín Asoc. Geógrafos Españoles 2019, 82, 1-36. [CrossRef]

104. Sariego, I.; Mazarrasa, K. Explorando la experiencia turística en Cantabria: Análisis del comportamiento de la demanda. Int. J. Sci. Manag. Tour. 2017, 3, 419-430.

105. Gil, C. Turismo y alojamiento hotelero en Cantabria. Algunas bases de análisis para la caracterización de la actividad turística regional. Boletín Asoc. Española Geografía 2008, 48, 277-309.

106. Sariego, I.; Moreno, A. La competitividad turística de Cantabria para la demanda potencial de la población del sur de Francia. Investig. Turísticas 2013, 5, 110-135. [CrossRef]

107. Fusté-Forné, F. Turismo en las cuevas: El patrimonio rupestre en Cantabria, España. Gran Tour Rev. Investig. Turísticas 2017, 16, 78-94.

108. Delgado, C.; Gil, C. Dinámica y desarrollo territorial de la Montaña Cantábrica: El ejemplo de las comarcas cántabras de Campoo y Cabuérniga-Tudanca. Ería 2008, 75, 53-76.

109. Cardona, R.; Serra, A. Características de la demanda del turismo rural de Baleares. RIAT Rev. Interam. Ambiente Tur. 2013, 9, 120-126.

110. Tur, V.; Garau, J.B. Agroturismo y Turismo Rural en Baleares; Estudis CAEB-CITTIB-Govern de les Illes Balears: Palma de Mallorca, Spain, 2002.

111. Moreno, S.; Cabrera Guillén, D.; López Galán, E.; de León Ledesma, J.; del Río Fresen, C.; Carballo Fuentes, R. El cambio de modelo turístico en las denominadas zonas no turísticas: Un acercamiento a través del posicionamiento adecuado. In El turismo en Canarias; del Mar Armas Cruz, Y., Ed.; Fundación FYDE-CajaCanarias: La Laguna, Spain, 2011; pp. 93-118.

112. Simancas, M.; Parra, E. ¿Existe un Modelo Turístico Canario? PROMOTUR Turismo Canarias, S.A: Santa Cruz de Tenerife, Spain, 2016.

113. Martín, C.S. Evolución del sistema turístico de la isla de El Hierro (Canarias). Cuad. Tur. 2009, 24, 111-133.

114. González, A.; Hernández, J.A.; Parreño, J.M. Los nuevos usos turísticos en la Reserva de la Biosfera de la isla de La Palma (Canarias). Boletín Asoc. Geógrafos Españoles 2016, 70, 239-257.

115. Sanagustín Fons, M.V.; Moseñe Fierro, J.A.; Gomez Patiño, M. Rural tourism: A sustainable alternative. Appl. Energy 2011, 88, 551-557.

116. Sanagustín Fons, M.V.; Moseñe Fierro, J.A.; Gomez Patiño, M.; Arena Luna, L. Sustainable Tourism in Aragon, a Case of a Spanish Inside Region. In Strategies for Tourism Industry. Micro and Macro Perspectives; Kasimoglu, M., Ed.; Intechopen: London, UK, 2012; pp. 79-98. Available online: https://www.intechopen.c om/books/strategies-for-tourism-industry-micro-and-macro-perspectives (accessed on 24 May 2020).

117. Sanagustín Fons, V.; Lafita-Cortés, T.; Moseñe, J.A. Social Perception of Rural Tourism Impact: A Case Study. Sustainability 2018, 10, 339. [CrossRef]

118. Giaccio, V.; Giannelli, A.; Mastronardi, L. Explaining determinants of Agritourism income: Evidence from Italy. Tour. Rev. 2018, 73, 216-229. [CrossRef]

119. Adamov, T.; Ciolac, R.; Iancu, T.; Brad, I.; Pet, E.; Popescu, G.; Smuleac, L. Sustainability of Agritourism Activity. Initiatives and Challenges in Romanian Mountain Rural Regions. Sustainability 2020, 12, 2502. [CrossRef] 
120. Choi, H.C.; Turk, E.S. Sustainability indicators for managing community tourism. In Quality-of-Life Community Indicators for Parks, Recreation and Tourism Management; Budruk, M., Phillips, R., Eds.; Springer: Dordrecht, The Netherlands, 2011; pp. 115-140.

121. Cernat, L.; Gourdon, J. Paths to success: Benchmarking cross-country sustainable tourism. Tour. Manag. 2012, 33, 1044-1056. [CrossRef]

(C) 2020 by the authors. Licensee MDPI, Basel, Switzerland. This article is an open access article distributed under the terms and conditions of the Creative Commons Attribution

(CC BY) license (http://creativecommons.org/licenses/by/4.0/). 